\title{
Palaeoproterozoic magnesite: lithological and isotopic evidence for playa/sabkha environments
}

\author{
VICTOR A. MELEZHIK*, ANTHONY E. FALLICK†, PAVEL V. MEDVEDEV $\$$ and \\ VLADIMIR V. MAKARIKHIN $\ddagger$ \\ ${ }^{*}$ Geological Survey of Norway, Leiv Eirikssons vei 39, 7491 Trondheim, Norway \\ (E-mail: victor.melezhik@ngu.no) \\ $\dagger$ Scottish Universities Environmental Research Centre, East Kilbride, Glasgow G75 0QF, UK \\ $\$$ Institute of Geology of Karelian Scientific Centre, Russian Academy of Sciences, Pushkinskaya, 11, \\ 185610 Petrozavodsk, Russian Karelia, Russia
}

\begin{abstract}
Magnesite forms a series of 1 - to 15 -m-thick beds within the $\approx 2 \cdot 0 \mathrm{Ga}$ (Palaeoproterozoic) Tulomozerskaya Formation, NW Fennoscandian Shield, Russia. Drillcore material together with natural exposures reveal that the 680m-thick formation is composed of a stromatolite-dolomite-'red bed' sequence formed in a complex combination of shallow-marine and non-marine, evaporitic environments. Dolomite-collapse breccia, stromatolitic and micritic dolostones and sparry allochemical dolostones are the principal rocks hosting the magnesite beds. All dolomite lithologies are marked by $\delta^{13} \mathrm{C}$ values from $+7 \cdot 1 \%$ o to $+11 \cdot 6 \%$ o (V-PDB) and $\delta^{18} \mathrm{O}$ ranging from $17 \cdot 4 \%$ to $26 \cdot 3 \%$ (V-SMOW). Magnesite occurs in different forms: finely laminated micritic; stromatolitic magnesite; and structureless micritic, crystalline and coarsely crystalline magnesite. All varieties exhibit anomalously high $\delta^{13} \mathrm{C}$ values ranging from $+9 \cdot 0 \%$ to $+11 \cdot 6 \%$ and $\delta^{18} \mathrm{O}$ values of $20 \cdot 0-25 \cdot 7 \%$. Laminated and structureless micritic magnesite forms as a secondary phase replacing dolomite during early diagenesis, and replaced dolomite before the major phase of burial. Crystalline and coarsely crystalline magnesite replacing micritic magnesite formed late in the diagenetic/metamorphic history. Magnesite apparently precipitated from sea water-derived brine, diluted by meteoric fluids. Magnesitization was accomplished under evaporitic conditions (sabkha to playa lake environment) proposed to be similar to the Coorong or Lake Walyungup coastal playa magnesite. Magnesite and host dolostones formed in evaporative and partly restricted environments; consequently, extremely high $\delta^{13} \mathrm{C}$ values reflect a combined contribution from both global and local carbon reservoirs. A ${ }^{13} \mathrm{C}$-rich global carbon reservoir $\left(\delta^{13} \mathrm{C}\right.$ at around $+5 \%$ is related to the perturbation of the carbon cycle at $2 \cdot 0 \mathrm{Ga}$, whereas the local enhancement in ${ }^{13} \mathrm{C}$ (up to $+12 \%$ ) is associated with evaporative and restricted environments with high bioproductivity.
\end{abstract}

Keywords Carbon, dolomite, isotopes, magnesite, oxygen, Palaeoproterozoic, playa, red beds, sabkha, stromatolite.

\section{INTRODUCTION}

Despite the fact that magnesite is a rare mineral in sedimentary rocks, it forms large-scale deposits, of which only two major types are exploited at present: ultramafic-hosted deposits of cryptocrystalline magnesite ('Kraubath type') and deposits of sparry magnesite within ancient marine platform 
carbonates ('Veitsch type'). Magnesite in lacustrine sediments in the vicinity of ultramafic rocks ('Bela Stena type') and metamorphosed ultramafic rocks with elevated magnesite content ('Greiner type') are of minor economic interest. In recent environments, magnesite occurs in coastal lakes and sabkhas and in continental playa lakes (Pohl, 1989).

Sedimentary-hosted magnesite deposits, being an exclusive feature of Neoproterozoic-Palaeozoic marine shelf sediments, may be considered, along with abundant associated dolomite, to be an important component of Earth's evolutionary history. Archaean (Schidlowski et al., 1975) and Palaeoproterozoic (Aharon, 1988) sedimentaryhosted magnesites have been described from very few localities. Magnesite mineralization from Palaeoproterozoic sedimentary environments of the Fennoscandian Shield has not yet been reported, although the possible presence of magnesite in Palaeoproterozoic dolostone sequences has long been recognized (e.g. Aksenov et al., 1975).

In this article, Palaeoproterozoic sedimentary magnesite mineralization from the $\approx 2$ billionyear-old Tulomozerskaya Formation (TF) of the NW Fennoscandian Shield (Fig. 1) is reported.
The magnesite mineralization occurs within the TF carbonates, which are marked by an extreme enrichment in ${ }^{13} \mathrm{C}$ reaching $+18 \%$ o (Yudovich et al., 1991). The TF carbonate sequence is part of the 2.3-2.06 Ga Palaeoproterozoic positive carbon isotope excursion (e.g. Baker \& Fallick, 1989; Karhu, 1993) and is marked by the greatest enrichment in ${ }^{13} \mathrm{C}$ known from the Precambrian (Melezhik et al., 1999).

This paper addresses the following: (i) the nature of the magnesite mineralization; (ii) depositional environments of the host carbonate sequence; and (iii) the possible significance of magnesite for understanding the extreme ${ }^{13} \mathrm{C}$-enrichment of the host dolostones.

\section{GEOLOGICAL BACKGROUND}

The local geology, stratigraphy and lithology were described in detail by Sokolov (1987). The TF is one of seven formations in the Palaeoproterozoic succession of the N. Onega Lake area. The Palaeoproterozoic succession starts with basal polymict conglomerates (Palozerskaya Formation; Fig. 1) unconformably overlying the Archaean substratum. The basal conglomerates are con-

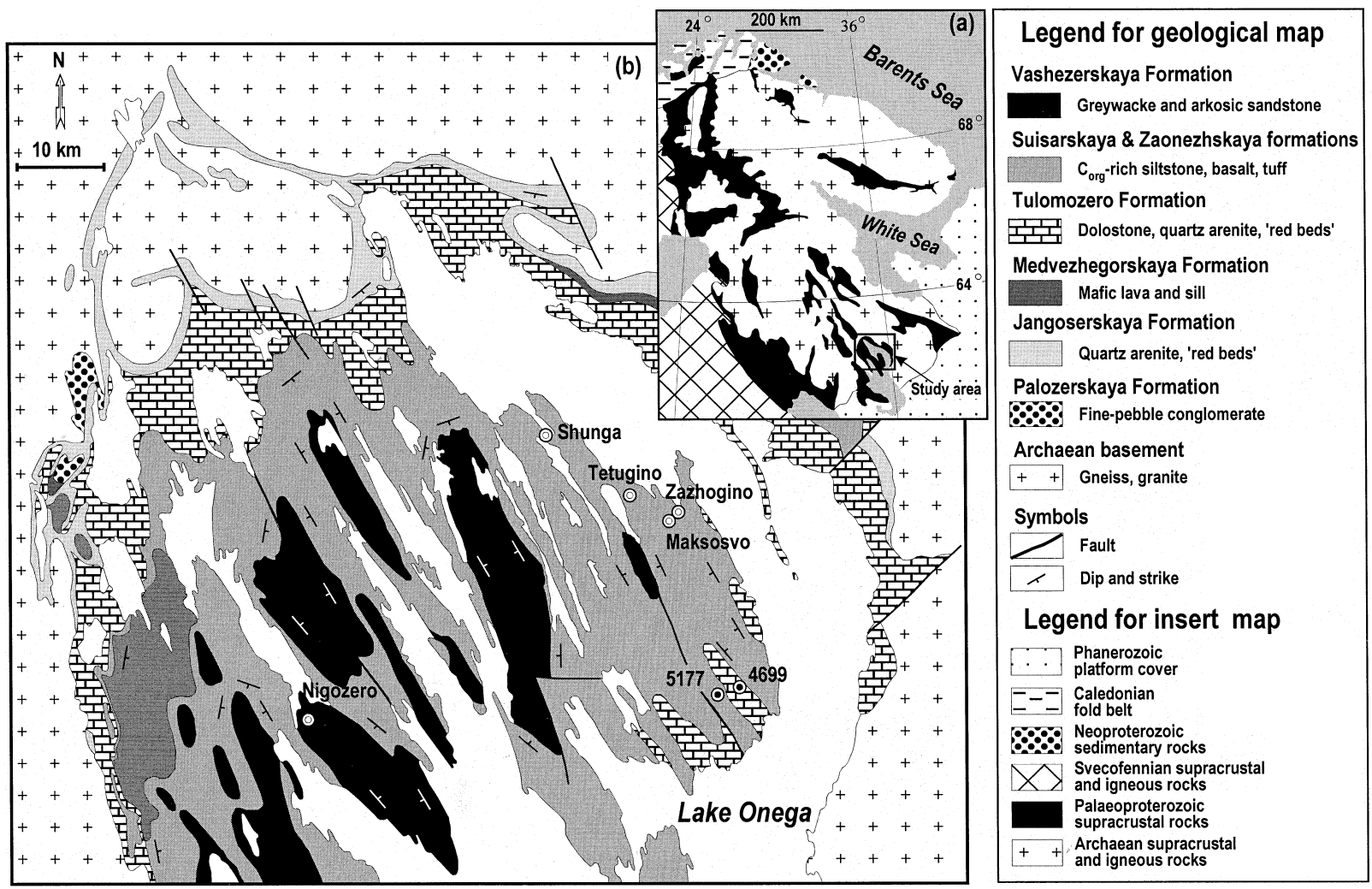

Fig. 1. (a) Geographical and geological location of the study area (marked by a square). (b) Geological map (the same area marked in the small box) of the northern Onega Lake area (simplified from Akhmedov et al., 1993). 
formably overlain by the 50- to 120 -m-thick Jangozersakaya Formation, which consists of red terrigenous rocks characterized by cross-bedding and desiccation cracks. These rocks are conformably overlain by the 70-m-thick Medvezhegorskaya Formation, which consists of mafic lava with subordinate pale grey and red, cross-bedded quartz arenites and fine-pebble conglomerates. The beds are conformably overlain by the TF, which is a 680-m-thick unit composed of stromatolitic dolostones, red quartz arenites and siltstones. This formation is, in turn, unconformably overlain by organic carbon-rich siltstones and mudstones with subordinate dolostones of the 1500-m-thick Zaonezhskaya Formation. The latter is followed by the Suisarskaya Formation, a 400-m-thick succession of basalts intercalated with numerous gabbro sills. A gabbro sill from the upper part of the Suisarskaya Formation has a Sm-Nd mineral isochron age of $1980 \pm 27 \mathrm{Ma}$ (Pukhtel' et al., 1992). The Palaeoproterozoic succession ends with the 190-m-thick Vashezerskaya Formation comprising greywacke and arkosic sandstones.

The entire sequence was deformed and underwent greenschist facies metamorphism during the $1 \cdot 8 \mathrm{Ga}$ Svekofennian orogeny. The paragenesis chlorite-actinolite-epidote reflects a temperature of $300-350{ }^{\circ} \mathrm{C}$ (Sokolov, 1987).

\section{LITHOSTRATIGRAPHIC POSITION OF MAGNESITE BEDS}

The magnesites cannot be distinguished from the host dolostones in hand samples and have been found as a result of systematic analysis. Five beds of magnesite and magnesite-bearing dolostones have been detected (Fig. 2). Four layers are in drillhole 5177 at depths of 553.5, 568.5, 598.7 and $799.0 \mathrm{~m}$. In drillhole 4699, magnesite-bearing dolostones occur at depths of $537.5 \mathrm{~m}$ and $758.0 \mathrm{~m}$ (Fig. 2). Most of the beds are apparently $<2 \mathrm{~m}$ thick, whereas the major magnesite bed (5177$553.5)$ is approximately $15 \mathrm{~m}$ thick. The lateral extent of magnesite-bearing beds is unknown. The thickest magnesite bed is sandwiched between two beds of dissolution-collapse breccia (Fig. 2).

\section{PETROGRAPHIC DESCRIPTION OF MAGNESITE}

The magnesite and magnesite-rich dolostone are white, grey or yellow. The magnesite beds are mainly composed of structureless micritic (5177568·5, Fig. 3), crystalline (5177-553.5, Fig. 4) and coarsely crystalline varieties. Finely laminated micritic, stromatolitic magnesite is rare (5177598.7).

The structureless micritic magnesite consists of micritic magnesite $(5-10 \mu \mathrm{m})$ with remnants of dolomite. Rare idiomorphic crystals $(0 \cdot 1-0 \cdot 3 \mathrm{~mm})$ of magnesite and dolomite developed in the micritic aggregate (Fig. 3) indicate recrystallization related to neomorphic/metamorphic processes. Micritic magnesite is also found in sparry allochemical dolostones with syntaxial dolomite cement. Here, small magnesite crystals are present within the dolomitic intraclasts and are absent in the syntaxial dolomite cement and crystalline dolomite matrix. If clear syntaxial overgrowths formed mainly in a burial environment (e.g. Tucker \& Wright, 1990), then the magnesite crystals probably replaced dolomite before most of the burial carbonate cements formed.

Micritic magnesite replaced dolomite pseudomorphically, producing very finely intergrown magnesite-dolomite aggregate (Fig. 4). From the micritic dolomite-magnesite relationship, it is obvious that magnesite could only have originated during early diagenesis if dolomite is a primary precipitate. Alternatively, magnesites may have formed somewhat later if dolomite is an early diagenetic replacement of a calcite precursor.

The structureless crystalline magnesite consists of $0 \cdot 1-0.5 \mathrm{~mm}$ idiomorphic or subidiomorphic magnesite crystals apparently replacing either micritic aggregate of 15-10 $\mu \mathrm{m}$ magnesite crystals (Fig. 4) and subordinate dolomite rhombs or silty dolomitic micrite. The coarsely crystalline magnesite has a larger grain size $(0 \cdot 5-2 \cdot 0 \mathrm{~mm})$ but exhibits similar relationships to the earlier phases of micritic dolomite and magnesite.

Micritic stromatolitic magnesite has undergone recrystallization. When fine lamination is preserved, the thin, pale grey laminae are predominantly composed of micrite, whereas thicker, light laminae consist of microsparite.

\section{LITHOF ACIES AND DEPOSITIONAL ENVIRONMENTS}

Ten lithofacies are recognized in the TF sequence (Table 1, Fig. 2). These lithofacies and their depositional environments have been described by Melezhik et al. (2000), who demonstrated that the TF was deposited in a variety of environments. Terrigenous 'red beds' present throughout 
Drill hole 5177

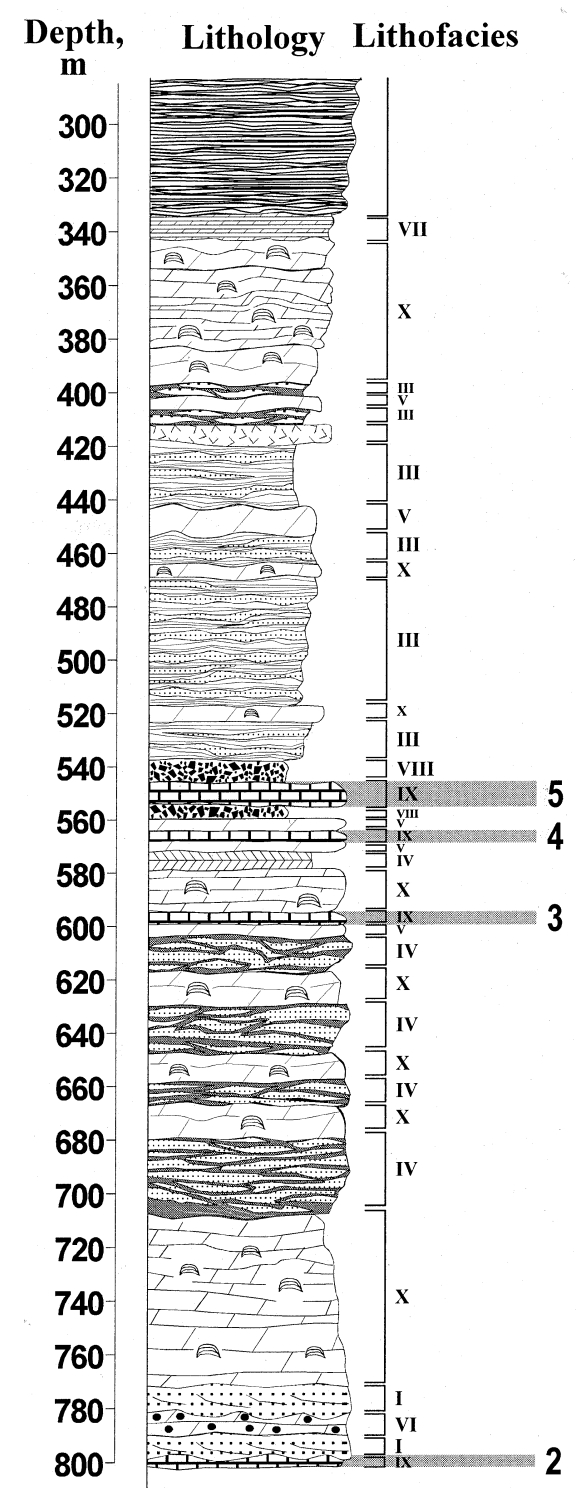

\section{Drill hole 4699}

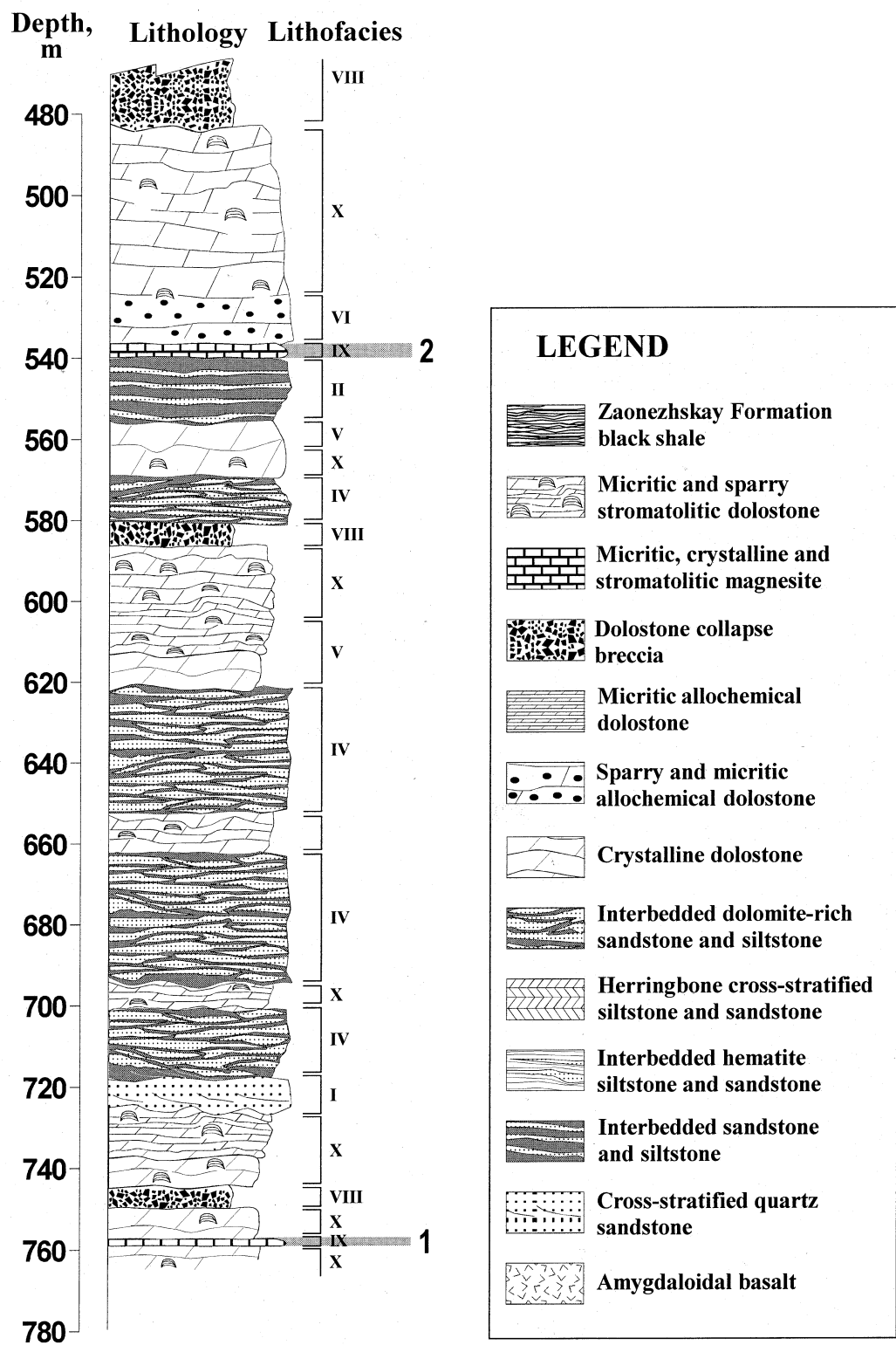

Fig. 2. Lithofacies and position of magnesite and magnesite-bearing dolostone beds in the TF intersected by drillholes 5177 and 4699. Magnesite beds are marked by grey bars.

the sequence formed in three main depositional settings: (i) a braided fluvial system over a lowenergy, river-dominated coastal plain (lithofacies I); (ii) a low-energy, barred, evaporitic lagoon (lithofacies II and IV-VII); and (iii) a non-marine, playa lake (lithofacies III and VIII). Biostromal and biohermal columnar stromatolitic dolostones (lithofacies X) are abundant and formed in shallow-water, low-energy, intertidal zones, barred evaporitic lagoons and peritidal evaporitic environments. The red, flat-laminated stromatolites formed in evaporative ephemeral ponds, coastal sabkhas and playa lakes. The presence of tepees, mudcracks, halite casts, pseudomorphs after calcium sulphate and abundant 'red beds' in the sequence suggests that terrestrial environments dominated over aqueous, with partial or total decoupling between the stromatolite-dominated depositional systems and nearby sea.

The magnesite has been designated as lithofacies IX (Melezhik et al., 2000).

Further details will only be given for those lithofacies that are closely associated with the five magnesite beds documented. 
Fig. 3. Photomicrographs showing large neomorphic crystals of magnesite (marked by 'M') and dolomite (marked by 'D') and micritic magnesite replacing micritic dolomite. (A) Plane-polarized light; (B) back-scattered electron image; (C) Ca X-ray map; (D) Mg X-ray map. Drillhole 5177, depth 568.5 m. 1 and 2 in (B) are positions of electron microprobe analyses shown in Table 3 .

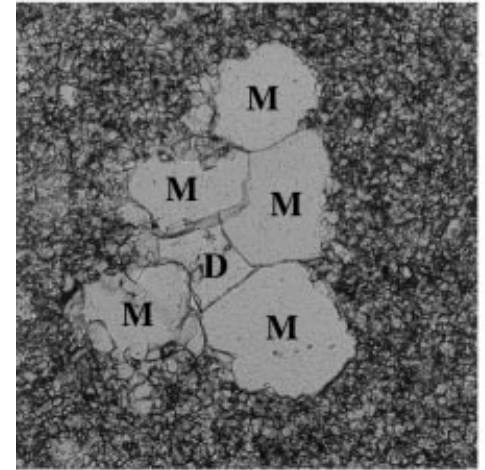

A

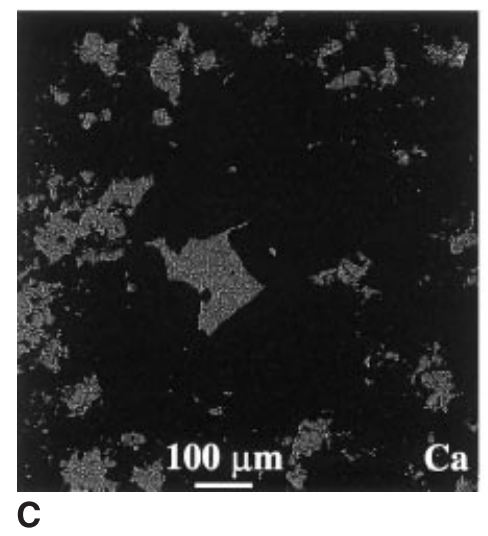

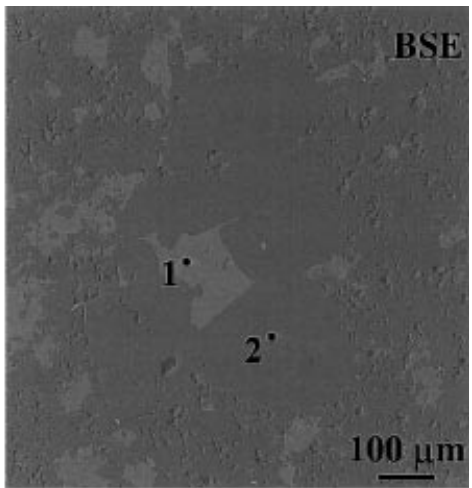

B

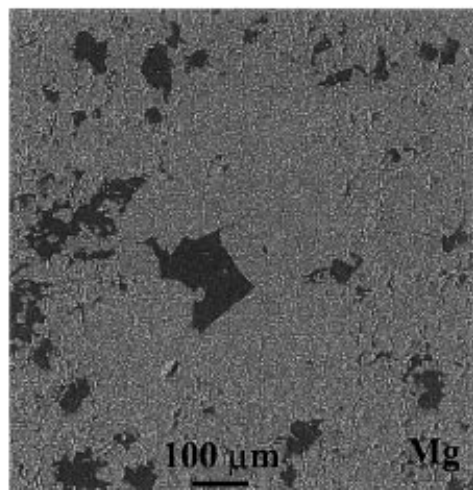

D
Bed 5 (Fig. 2) is the major magnesite occurrence. It is sandwiched between the dissolution-collapse breccia of lithofacies VIII. The magnesite-collapse breccia assemblage is overlain by lithofacies III, which consists of intercalated brown, mudcracked, haematite-rich siltstones and pink, platy, cross-stratified, dolomite-cemented quartz arenites. Fine laminae in lithofacies III typically form low-relief hummocks and swells with amplitudes of less than $1 \mathrm{~cm}$ and wavelengths of $1-3 \mathrm{~cm}$. A 1-to 2-m-thick bed of clastic haematite ore and halite cube casts in siltstones have also been reported (Akhmedov et al., 1993). Lithofacies III is similar to the terrestrial 'red bed'-dolostonehalite association in the Bitter Spring Formation in the Amadeus Basin, Australia, which formed in a series of shallow, hypersaline lakes and ponds (Southgate, 1986).

The presence of halite casts and the absence of calcium sulphate evaporites is also consistent with a non-marine origin for lithofacies III. The abundant desiccation cracks and the presence of small-wavelength wave ripples suggest deposition in a playa lake.

The dissolution-collapse breccia, which hosts the Bed 5 magnesite, appears as poorly cemented fragments of brown, pink and white dolostones and brown, finely laminated mudstones either embedded in insoluble residues or cemented by coarsely crystalline dolomite (Fig. 5A). The insoluble residues are composed of dark brown dolomite-sericite-chlorite material enriched in iron oxide. As no palaeokarst surfaces have been observed, the subsurface dissolution of evaporite minerals was probably the main process that led to the development of the collapse breccias. Sedimentological data match a playa lake or sabkha environment (Melezhik et al., 2000). The close spatial relationship of Bed 5 to lithofacies III and VIII indicates that it formed either in a playa lake or in a ponded tidal flat setting under evaporitic conditions.

Bed 3 rests on lithofacies $\mathrm{V}$ and is overlain by lithofacies X. Bed 4 is entirely associated with lithofacies $\mathrm{V}$, which consists of variegated, structureless or indistinctly parallel-laminated dolostones, marls and mudstones. The rocks are sporadically marked by desiccation cracks and by dolomite pseudomorphs after displacive, isolated, small crystals of gypsum (Akhmedov et al., 1993). Some of these pseudomorphs have 'swallow tail' twin morphology (Fig. 5B). The desiccation cracks are filled with quartz sand, are several decimetres wide and penetrate $2-3 \mathrm{~cm}$. 


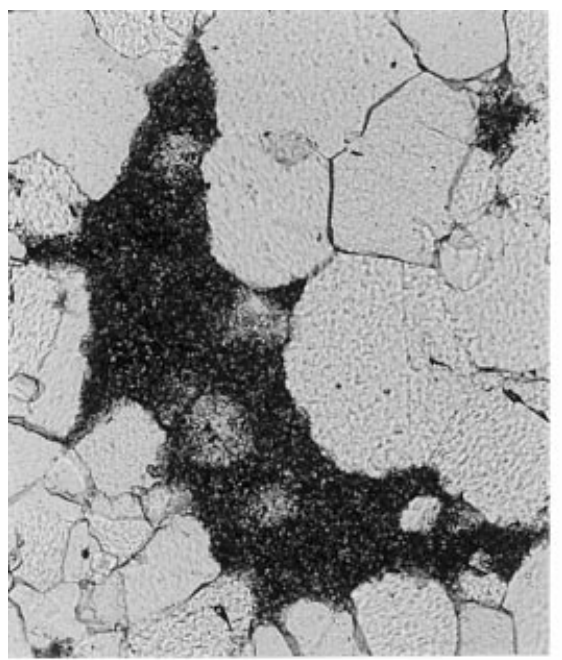

A

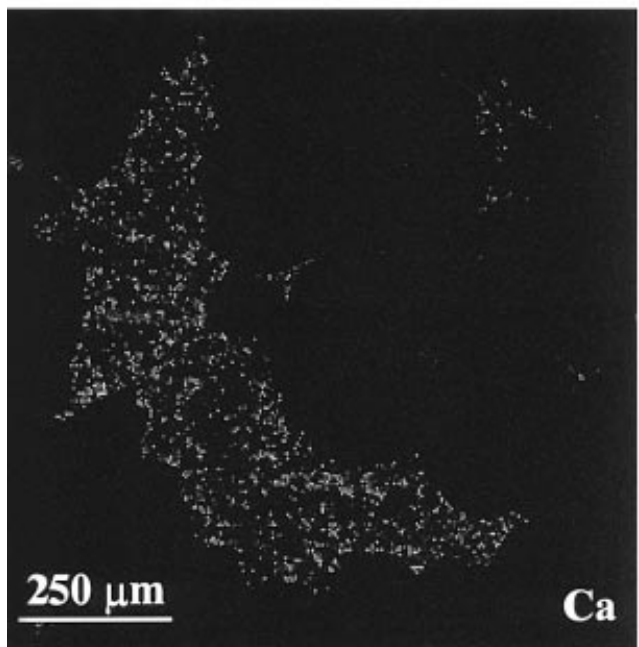

C

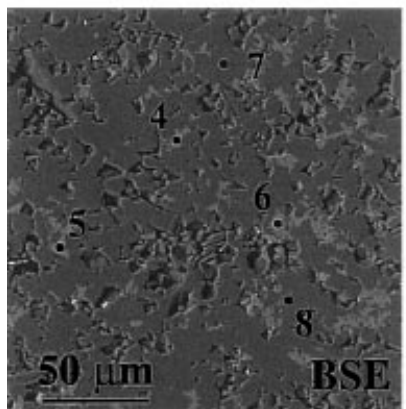

$\mathrm{E}$

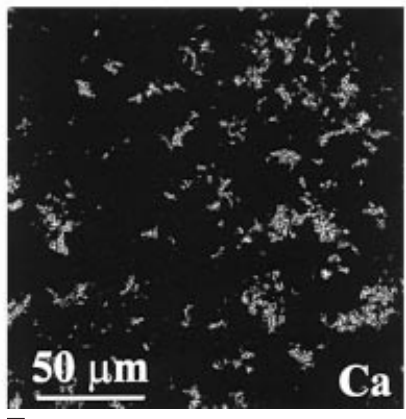

$\mathbf{F}$

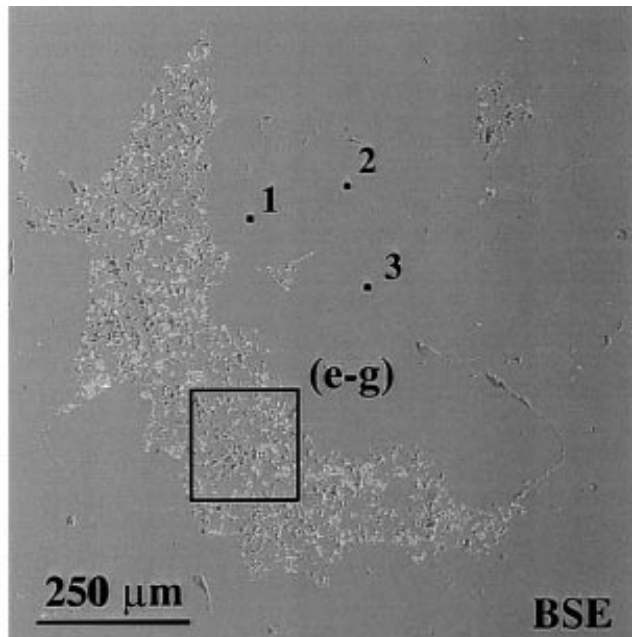

B

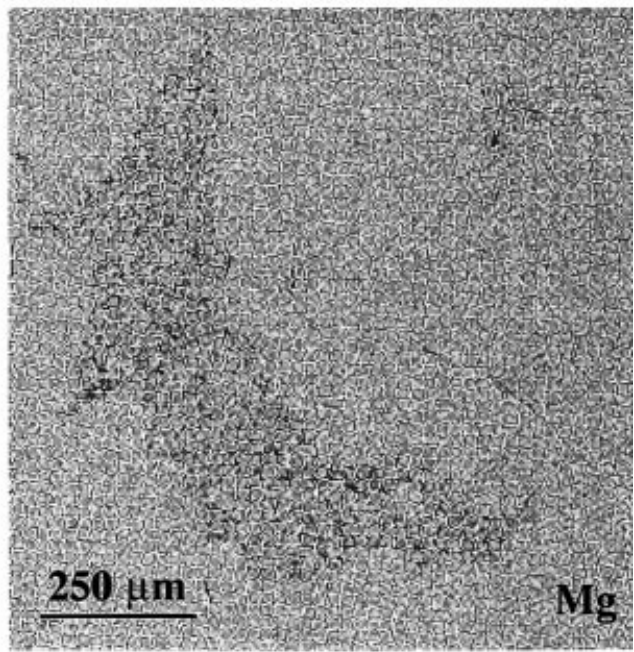

D

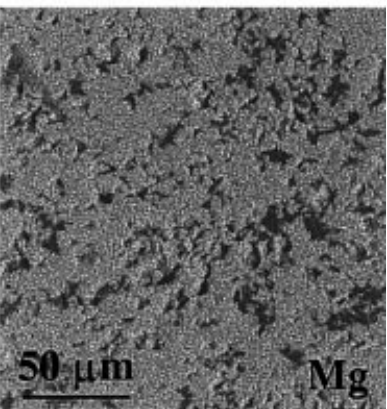

G

Fig. 4. Photomicrographs showing large crystals of magnesite replacing aggregate of micritic magnesite and dolomite. (A) Plane-polarized light; (B) back-scattered electron image; (C) Ca X-ray map; (D) Mg X-ray map. (E-G) Magnified views of intergrown magnesite-dolomite mixture. (E) Back-scattered electron image; (F) Ca X-ray map; (G) Mg X-ray map. Drillhole 5177, depth 553.5 m. 1-3 in (B) and 4-8 in (E) are positions of electron microprobe analyses shown in Table 3.

Syndepositional deformation is expressed as tepee structures (Akhmedov et al., 1993). The lack of post-depositional compaction of the des- iccation cracks suggests that the lithification occurred before burial (Melezhik et al., 2000). This is consistent with the depositional environment, 


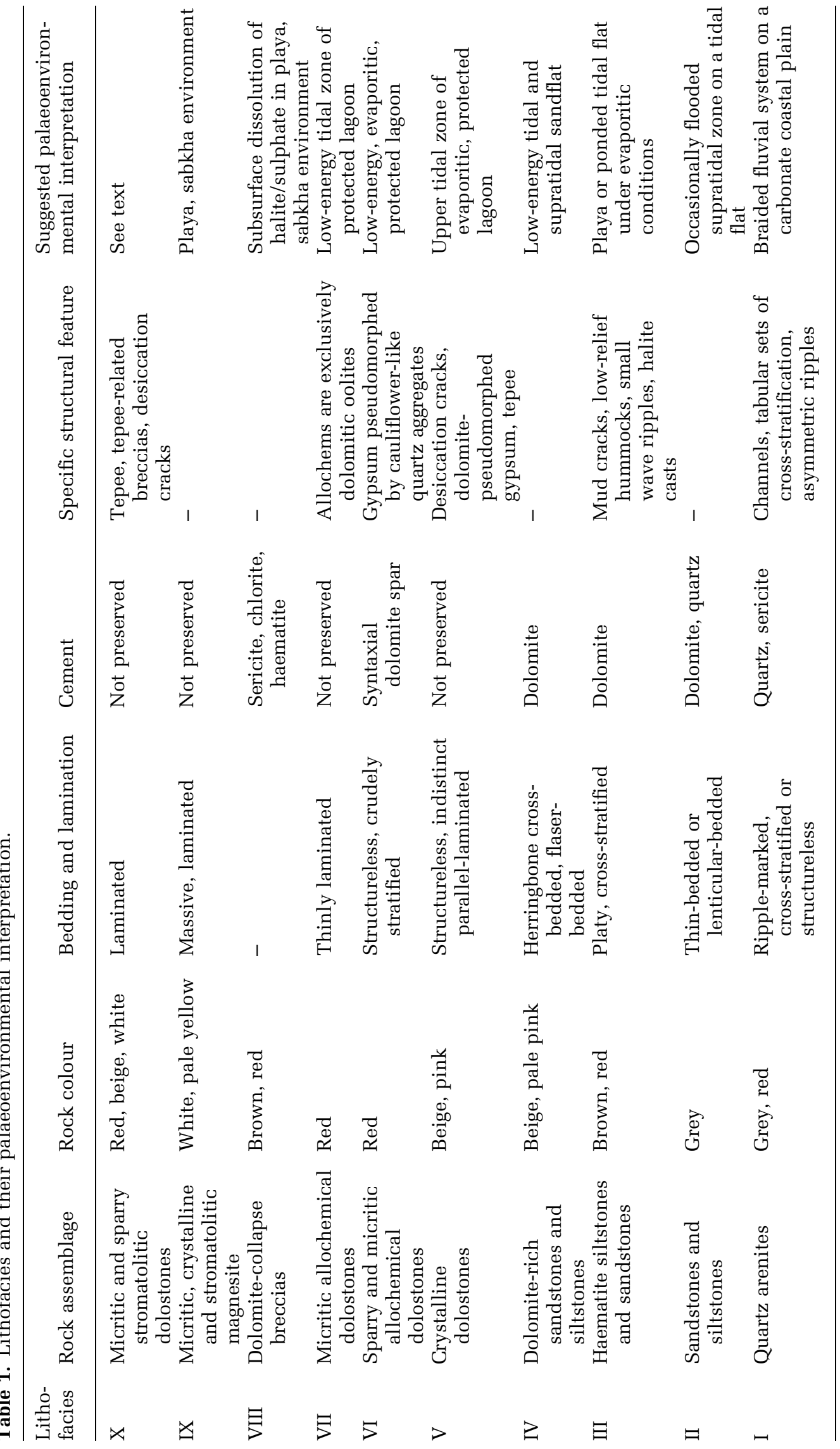



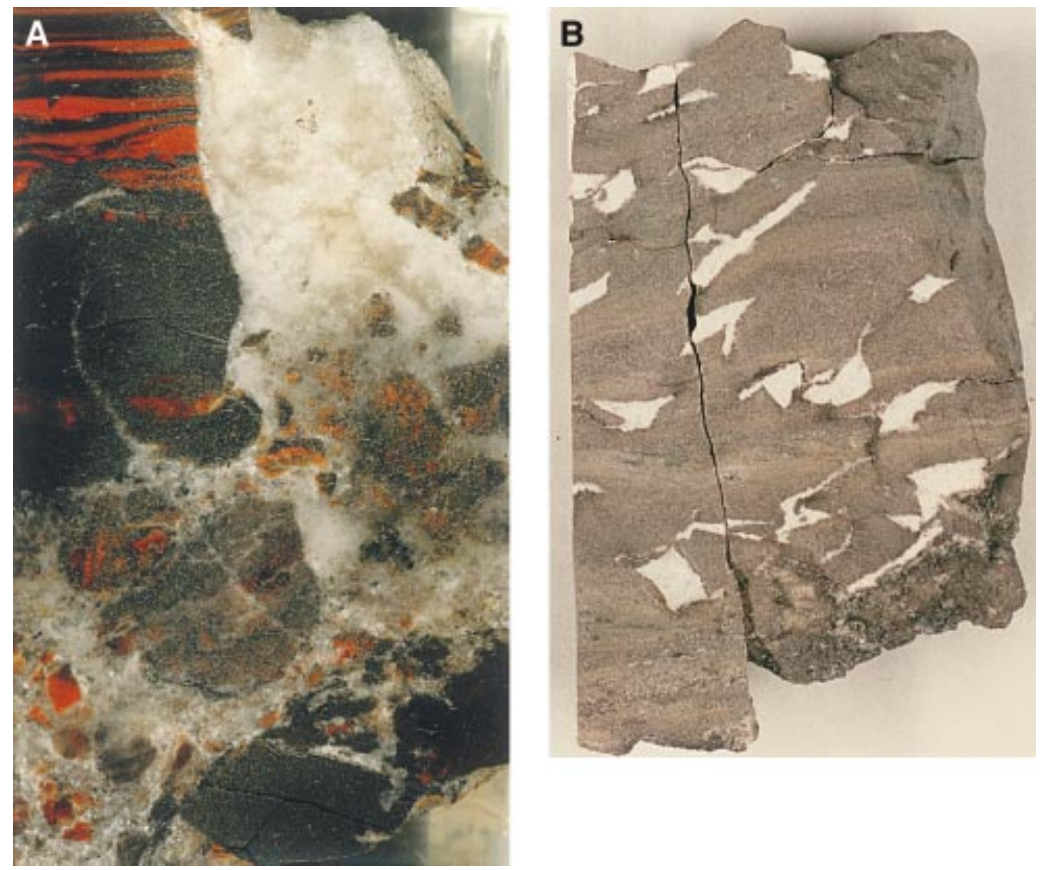

Fig. 5. (A) Dissolution-collapse breccia consisting of fragments of brown, pink, massive and finely laminated mudstones cemented by coarsely crystalline dolomite. Lithofacies VIII, drillhole 5177, depth $542 \cdot 0 \mathrm{~m}$. Core diameter is $42 \mathrm{~mm}$. (B) Dolomite-pseudomorphed crystals of gypsum exhibiting 'swallow tail' twin morphology. Lithofacies V, drillhole 5177, depth $570.0 \mathrm{~m}$. Core diameter is $42 \mathrm{~mm}$.

which was affected by long-term subaerial exposure, allowing the carbonate sediments to become lithified. The observed 'swallow tail' twin morphology of dolomite pseudomorphed gypsum crystals closely resembles those reported from ancient rocks elsewhere (Rubin \& Friedman, 1977; Spencer \& Lowenstein, 1990). The lithofacies $\mathrm{V}$ gypsum appears to have precipitated penecontemporaneously with the dolomite from shallow, near-surface brines (Melezhik et al., 2000). Because intrasediment gypsum growth provides unequivocal evidence of post-depositional crystallization in an evaporitic environment (Demicco \& Hardie, 1994), similar conditions are proposed for lithofacies V. Overall, the sedimentological data suggest that the micritic dolostones of lithofacies $\mathrm{V}$ and the associated magnesites of Beds 3 and 4 formed in a shallow-water, evaporative setting. The tepee structures suggest that the carbonate rocks were subaerially exposed for extended periods.

Bed 2 magnesite has close association with lithofacies I, II and VI. Lithofacies II does not contain reliable genetic information. However, the main diagnostic features of lithofacies I, such as the dominance of sand, lack of silty and muddy particles, unidirectional cross-stratification, generally fining-upward sequence and presence of erosional channels, are consistent with braided fluvial systems over a low-energy, river-dominated coastal, carbonate plain. Lithofacies VI is a red grainstone, which is typically structureless or crudely stratified by variations in colour and grain size. Allochems include unsorted, rounded and angular intraclasts of dolostone and sporadic haematite and siliceous oolites. Abundant vugs, voids and cauliflower-like aggregates of quartz (with both castellated margins and mammillated surfaces) with crude radial fabric are common. Given the lack of micrite in lithofacies VI grainstones, the depositional setting must have had sufficient current or wave energy to winnow away the fine matrix (Folk, 1962). However, the unsorted, mixed rounded and angular intraclasts suggest that the depositional environment has only occasionally been influenced by such currents and waves. Another diagnostic feature is abundant cauliflower-like aggregates of quartz, which are pseudomorphs after calcium sulphate nodules (Melezhik et al., 2000). The discovery of solitary anhydrite nodules, tens of millimetres to $0.25 \mathrm{~m}$ in diameter, in the Holocene sediments of the Persian Gulf (Curtis et al., 1963; Shearman, 1966) led to the development of 'carbonateevaporite' or 'sabkha' depositional models to explain some ancient shallow-marine carbonate deposits (Shinn, 1983; James, 1984; Hardie \& Shinn, 1986). Thus, overall, the data suggest that lithofacies II and VI, and the associated magnesite Bed 2, formed in a barred, river-dominated, coastal, evaporative carbonate plain, occasionally influenced by tidal currents and waves.

Bed 1 magnesite is hosted by lithofacies X red, haematite-rich, flat-laminated stromatolites that 
form relief sheets. The stromatolite sheets are very often cracked and characterized by either indistinct, clotted or ribbon fabric with polygonal prism cracks. The presence of blisters, clotted fabrics with fenestrae and abundant desiccation cracks suggests that the flat-laminated stromatolites and associated magnesite Bed 1 formed in drained depressions and ephemeral ponds on a carbonate flat (playa lake or sabkha environment).

\section{SAMPLES AND ANALYTICAL METHODS}

Magnesite and dolomite samples were obtained from drillcores. The drillholes $5177\left(35^{\circ} 25^{\prime} 00^{\prime \prime} \mathrm{E}\right.$, $\left.62^{\circ} 14^{\prime} 29^{\prime \prime} \mathrm{N}\right)$ and $4699\left(35^{\circ} 28^{\prime} 00^{\prime \prime} \mathrm{E}, 62^{\circ} 14^{\prime} 30^{\prime \prime} \mathrm{N}\right)$ were made by the Karelian Geological Expedition. Both drillholes are $800 \mathrm{~m}$ deep; they partly overlap and intersect the entire thickness $(680 \mathrm{~m})$ of the TF.

Whole-rock oxygen and carbon isotope analyses were carried out at the Scottish Universities Environmental Research Centre using the phosphoric acid method described by McCrea (1950) and modified by Rosenbaum \& Sheppard (1986) for operation at $100{ }^{\circ} \mathrm{C}$. Carbon and oxygen isotope ratios were measured on a VG SIRA 10 mass spectrometer. Calibration to international reference material was through NBS 19, and precision $(1 \sigma)$ for both isotope ratios is better than $\pm 0 \cdot 2 \%$. Oxygen isotope data were corrected using the fractionation factor 1.00913 for dolomites and 1.00933 for magnesite recommended by Rosenbaum \& Sheppard (1986). The $\delta^{13} \mathrm{C}$ data are reported in per mil $(\%)$ relative to V-PDB and the $\delta^{18} \mathrm{O}$ data in \%o relative to $\mathrm{V}$-SMOW.

Because the magnesite and dolomite are commonly intergrown, the chemistry (XRF) and stable isotopic composition of the samples were obtained by whole-rock analysis, with additional electron microprobe (EMP) measurements to detect small-scale chemical variation. A sequential acid reaction was used in an attempt to resolve isotopic composition of different mineralogical components in finely intergrown mixtures of magnesite and dolomite. The approach was based on the procedures recommended by AlAasm et al. (1990). A three-step sequential dissolution with phosphoric acid was used on $10 \mathrm{mg}$ aliquots: (i) $2 \mathrm{~h}$ at $25^{\circ} \mathrm{C}$ to react calcite; (ii) $24 \mathrm{~h}$ at $50{ }^{\circ} \mathrm{C}$ to react dolomite; (iii) 2 days at $100{ }^{\circ} \mathrm{C}$ to react magnesites.

The major and trace elements were analysed by X-ray fluorescence spectrometry at the Geological Survey of Norway using a Philips PW 1480 X-ray spectrometer. The accuracy $(1 \sigma)$ is typically better than $2 \%$ of the oxide present $\left(\mathrm{SiO}_{2}\right.$, $\mathrm{Al}_{2} \mathrm{O}_{3}, \mathrm{MgO}, \mathrm{CaO}$ ), even at the level of 0.05 $\mathrm{wt} \%$, and the precision is almost invariably higher than the accuracy. The analytical uncertainties $(1 \sigma)$ for $\mathrm{Sr}, \mathrm{MnO}$ and $\mathrm{Fe}_{2} \mathrm{O}_{3}$ are better than $\pm 5 \cdot 5$ p.p.m., $\pm 0 \cdot 003 \%$ and $\pm 0 \cdot 01 \%$ respectively.

Back-scattered electron imaging, EMP measurements and cathodoluminescence of carbonate minerals were carried out at the Institute of the Continental Shelf in Trondheim. A Jeol 733 SEM Microprobe (Noran Instruments) with a silicon/ lithium detector and Norwar window type were used. The operating conditions were as follows: take-off angle $40^{\circ}$, acceleration voltage $15 \mathrm{kV}$, beam current $15 \mathrm{nA}$, beam diameter $1 \mu \mathrm{m}$, working distance $11 \mathrm{~mm}$. A Proza-type matrix correction (fourth generation) was used. The detection limit for $\mathrm{Ca}, \mathrm{Mg}, \mathrm{Fe}$ and $\mathrm{Mn}$ is $\mathbf{0 . 1} \mathrm{wt} \%$ (energy dispersive spectrometer). The following calibration standard references were used: calcite for $\mathrm{Ca}$, dolomite for $\mathrm{Mg}$, magnetite for $\mathrm{Fe}$, bustamite for $\mathrm{Mn}$.

\section{GEOCHEMICAL RESULTS}

Fifteen whole-rock samples of dolostone and four samples of magnesite from drillholes 5177 and 4699 were analysed for oxygen and carbon isotopes as well as for major and trace elements (Table 2). Results of electron microprobe analysis carried out on the selected samples are presented in Table 3. Additionally, a sequential acid reaction with subsequent oxygen and carbon isotope analyses was used for 28 composite dolomitemagnesite samples (Table 4).

\section{Dolostone}

$\mathrm{Mg} / \mathrm{Ca}$ ratios of the dolostone dolomite, based on EMP measurements, range from 0.46 to 0.63 (Table 3) with an average of $0 \cdot 55$, which is lower than that for stoichiometric dolomite $(0 \cdot 62)$.

The spread in oxygen and carbon isotope values is from $17 \cdot 4 \%$ to $26.3 \%$ (mean $21 \cdot 5 \pm 1 \cdot 7 \%$ ) and from $+7 \cdot 1 \%$ to $+11 \cdot 6 \%$ (mean $+9 \cdot 6 \pm 1 \cdot 3 \%$ o respectively. Cross-plots reveal no statistically significant covariation between $\delta^{13} \mathrm{C}$ and $\delta^{18} \mathrm{O}$ (Fig. 6). There is no relationship between the $\mathrm{Mg} / \mathrm{Ca}$ ratio and $\mathrm{C} / \mathrm{O}$ isotopes, nor between $\mathrm{Mn}, \mathrm{Mn} / \mathrm{Sr}$ and $\mathrm{C} / \mathrm{O}$ isotopic values. Sr and $\delta^{13} \mathrm{C}$ and $\mathrm{Sr}$ and $\delta^{18} \mathrm{O}$ show positive covariation, $r=0.70$ and $r=0 \cdot 48$ respectively. 


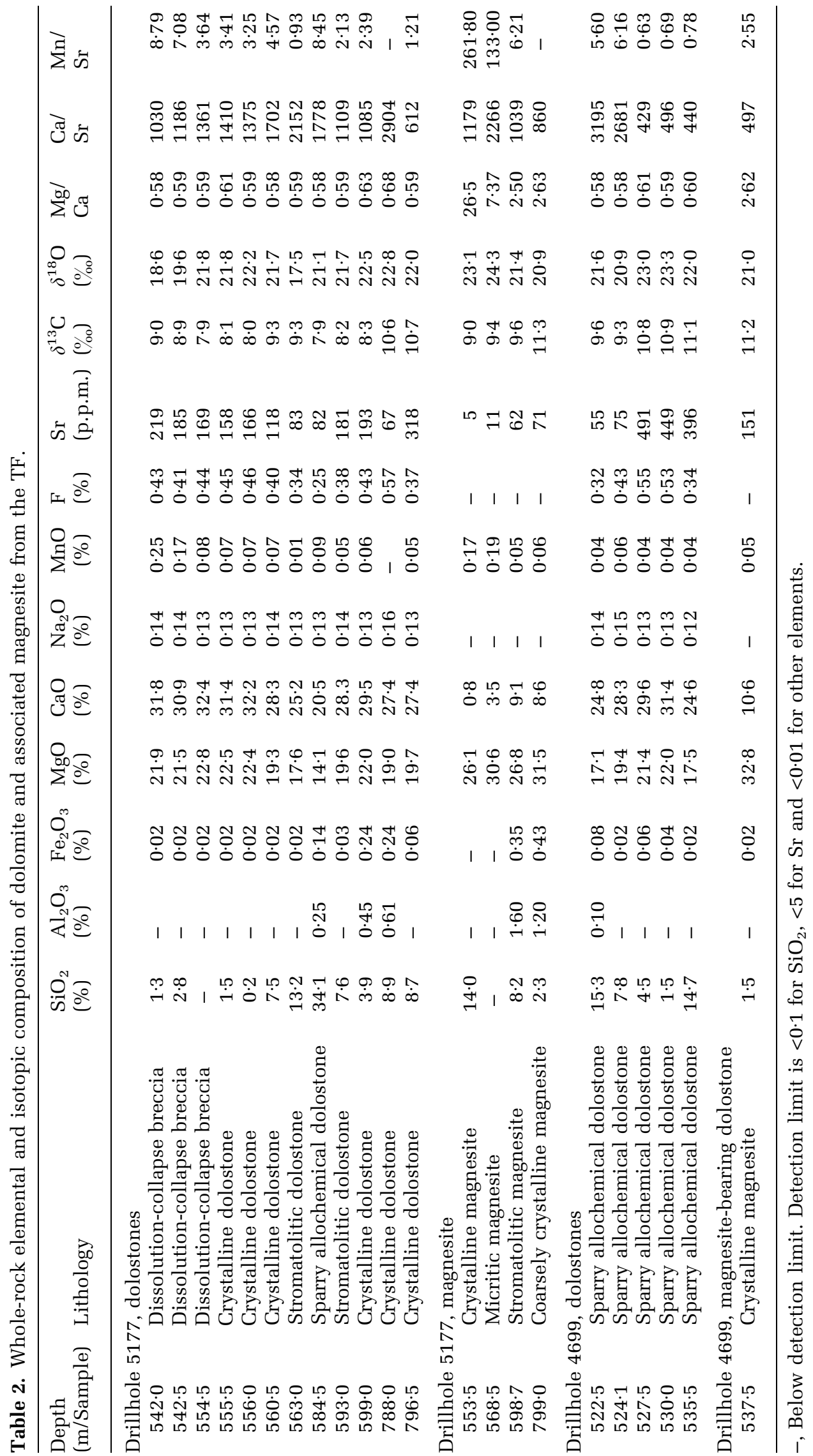



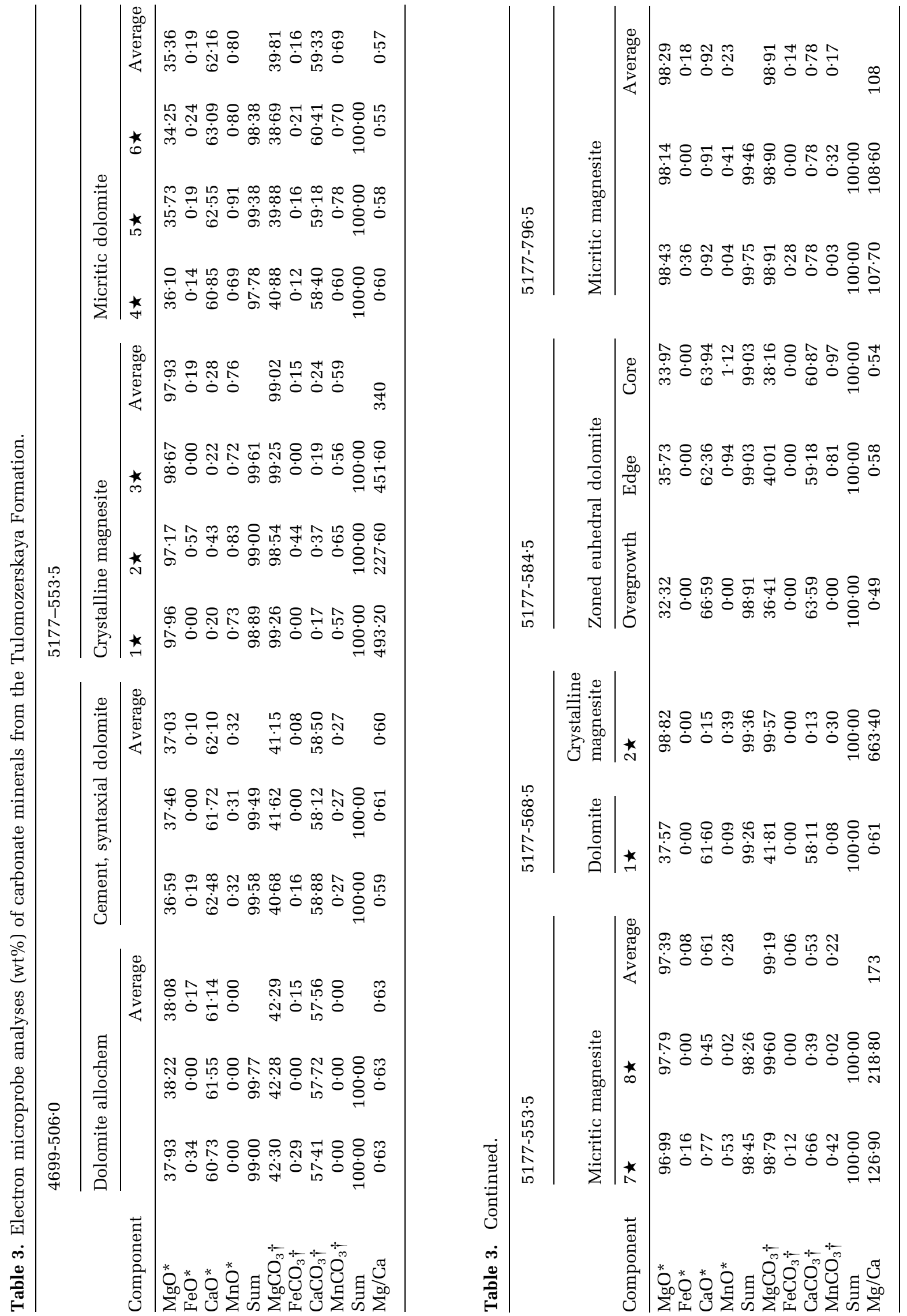


\section{Magnesite}

The whole-rock XRF analyses indicate that the five beds of magnesite and magnesite-bearing dolostones are characterized by $\mathrm{Mg} / \mathrm{Ca}$ ratios that increase upwards through the sequence from $2 \cdot 6$ to 26.5 (Table 2). This indicates that the concentration of magnesite increases upwards through the sequence with the culmination in upper magnesite Bed 5. The magnesites have lower $\mathrm{Na}$ and $\mathrm{F}$ contents than the dolomites (below detection limits; Table 2). They are also depleted in $\mathrm{Sr}$ ( $<5-151$ p.p.m. averaging 57 p.p.m.) compared with the dolomites. However, in the case of magnesite, Sr having a larger ionic radius should substitute only for Ca (similar to dolomite; Kretz, 1982; Reeder, 1983). If the Sr concentrations are normalized to $\mathrm{Ca}$, there is no difference between magnesites and host dolostones.

EMP measurements suggest that the $\mathrm{Mg} / \mathrm{Ca}$ ratios of the magnesite correlate with the petrography of the rocks. Large magnesite crystals (neomorphic/metamorphic magnesite) have high $\mathrm{Mg} / \mathrm{Ca}$ ratios (230-663), whereas the $\mathrm{Mg} / \mathrm{Ca}$ ratios of micritic magnesite drop to 108-172, which corresponds to $0.78-0.53 \mathrm{CaCO}_{3} \mathrm{wt} \%$ (Table 3 ). The overall $\mathrm{CaCO}_{3}$ content of the magnesite is low, in the range $0 \cdot 13-0 \cdot 78 \mathrm{wt} \%$ (Table 3 ). The micritic magnesite is marked by a relatively enhanced $\mathrm{CaCO}_{3}$ content $(0.53 \mathrm{wt} \%$ on average) compared with the crystalline and coarsely crystalline neomorphic magnesite $(0.24 \mathrm{wt} \%$ on average). The crystalline and coarsely crystalline magnesite is relatively enriched in Mn compared with micritic magnesite.

$\delta 13 \mathrm{C}$ and $\delta^{18} \mathrm{O}$ values range from $+9 \cdot 0 \%$ to $+11 \cdot 6 \%$ o (mean $+10 \cdot 1 \pm 1 \cdot 0 \%$ ) and from $20 \cdot 0 \%$ to $25 \cdot 7 \%$ (mean $22 \cdot 2 \pm 1 \cdot 7 \%$ ) respectively. Overall, the magnesites and their host dolostones are rather similar in carbon isotope ratios (Fig. 6, Table 4). However, the Bed 4 magnesite is characterized by slightly elevated $\delta^{18} \mathrm{O}$ values $(25 \cdot 0 \%$ on average) compared with the average host dolostone $(21.3 \%$, Table 2$)$ and intergrown dolomite $(21 \cdot 6 \%$, Table 4$)$.

\section{EVALUATION OF DIAGENESIS AND METAMORPHISM}

There is growing evidence that dolomite in the Precambrian precipitated either directly from sea water (Tucker, 1982) or by dolomitization during early diagenesis caused by waters isotopically comparable with sea water (e.g. Veizer \& Hoefs, 
Table 4. Carbon and oxygen isotope analyses of composite dolomitemagnesite samples using selective acid extraction.

\begin{tabular}{|c|c|c|c|c|c|c|}
\hline \multirow[b]{2}{*}{ Depth (m/sample) } & Yield (\%) & $\delta^{13} \mathrm{C}$ & $\delta^{18} \mathrm{O}$ & Yield (\%) & $\delta^{13} \mathrm{C}$ & $\delta^{18} \mathrm{O}$ \\
\hline & \multicolumn{3}{|l|}{ Dolomite } & \multicolumn{3}{|l|}{ Magnesite } \\
\hline \multicolumn{7}{|l|}{ Magnesite Bed 2} \\
\hline $4699-537 \cdot 5^{*}$ & & & & & $11 \cdot 2$ & $21 \cdot 0$ \\
\hline $4699-537 \cdot 5$ & 24 & $11 \cdot 2$ & $21 \cdot 7$ & 76 & $11 \cdot 6$ & $20 \cdot 8$ \\
\hline $4699-537 \cdot 6$ & 36 & $11 \cdot 4$ & $22 \cdot 3$ & 64 & $11 \cdot 5$ & $20 \cdot 6$ \\
\hline $4699-537 \cdot 7$ & 33 & $11 \cdot 4$ & $22 \cdot 6$ & 67 & $11 \cdot 6$ & $20 \cdot 8$ \\
\hline $4699-537 \cdot 8$ & 24 & $11 \cdot 3$ & $22 \cdot 7$ & 76 & $11 \cdot 6$ & $21 \cdot 0$ \\
\hline $4699-537 \cdot 9$ & 38 & $11 \cdot 3$ & $22 \cdot 1$ & 62 & $11 \cdot 5$ & $20 \cdot 8$ \\
\hline \multicolumn{7}{|l|}{ Magnesite Bed 5} \\
\hline $5177-553 \cdot 5^{*}$ & & & & & $9 \cdot 0$ & $23 \cdot 1$ \\
\hline $5177-553 \cdot 5$ & 0 & - & - & 100 & $9 \cdot 2$ & $23 \cdot 2$ \\
\hline $5177-553 \cdot 55$ & 10 & $9 \cdot 0$ & $23 \cdot 4$ & 90 & $9 \cdot 2$ & $23 \cdot 7$ \\
\hline $5177-553 \cdot 6$ & 0 & - & - & 100 & $9 \cdot 2$ & $23 \cdot 1$ \\
\hline $5177-553 \cdot 6$ & 0 & - & - & 100 & $9 \cdot 1$ & $23 \cdot 6$ \\
\hline $5177-553 \cdot 65$ & 10 & $7 \cdot 8$ & $22 \cdot 1$ & 90 & $9 \cdot 0$ & $23 \cdot 6$ \\
\hline $5177-553 \cdot 7$ & 6 & $9 \cdot 9$ & $26 \cdot 3$ & 94 & $9 \cdot 3$ & $23 \cdot 8$ \\
\hline $5177-553 \cdot 8$ & 0 & - & - & 100 & $9 \cdot 3$ & $23 \cdot 9$ \\
\hline $5177-553 \cdot 9$ & 6 & $8 \cdot 8$ & $22 \cdot 0$ & 74 & $9 \cdot 1$ & $23 \cdot 7$ \\
\hline \multicolumn{7}{|l|}{ Magnesite Bed 4} \\
\hline $5177-568 \cdot 5^{*}$ & & & & & $9 \cdot 4$ & $24 \cdot 3$ \\
\hline $5177-568 \cdot 5$ & 9 & $9 \cdot 2$ & $21 \cdot 8$ & 91 & $9 \cdot 8$ & $24 \cdot 6$ \\
\hline $5177-568 \cdot 7$ & 18 & $9 \cdot 7$ & $23 \cdot 2$ & 82 & $9 \cdot 8$ & $25 \cdot 7$ \\
\hline $5177-568 \cdot 8$ & 15 & $9 \cdot 3$ & $22 \cdot 0$ & 85 & $9 \cdot 8$ & $25 \cdot 4$ \\
\hline $5177-568 \cdot 9$ & $10 \cdot 5$ & $9 \cdot 6$ & $22 \cdot 0$ & $89 \cdot 5$ & $9 \cdot 7$ & $24 \cdot 8$ \\
\hline \multicolumn{7}{|l|}{ Magnesite Bed 3} \\
\hline $5177-598 \cdot 7^{*}$ & & & & & $9 \cdot 6$ & $21 \cdot 4$ \\
\hline $5177-598 \cdot 7$ & 21 & $9 \cdot 0$ & $20 \cdot 7$ & 79 & $9 \cdot 7$ & $20 \cdot 3$ \\
\hline $5177-598 \cdot 7$ & 42 & $9 \cdot 6$ & $23 \cdot 2$ & 58 & $9 \cdot 6$ & $21 \cdot 8$ \\
\hline $5177-598 \cdot 75$ & 0 & - & - & 100 & $9 \cdot 5$ & $21 \cdot 0$ \\
\hline $5177-598 \cdot 8$ & 24 & $9 \cdot 3$ & $20 \cdot 6$ & 76 & $9 \cdot 5$ & $20 \cdot 8$ \\
\hline $5177-598 \cdot 85$ & $22 \cdot 5$ & $7 \cdot 1$ & $17 \cdot 4$ & $77 \cdot 5$ & $9 \cdot 5$ & $21 \cdot 8$ \\
\hline $5177-598 \cdot 9$ & 14 & $7 \cdot 5$ & $18 \cdot 1$ & 86 & $9 \cdot 0$ & $20 \cdot 0$ \\
\hline $5177-598 \cdot 95$ & 21 & $9 \cdot 3$ & $20 \cdot 8$ & 79 & $9 \cdot 6$ & $21 \cdot 2$ \\
\hline \multicolumn{7}{|l|}{ Magnesite Bed 1} \\
\hline $5177-799 \cdot 0^{*}$ & & & & & $11 \cdot 3$ & $20 \cdot 9$ \\
\hline $5177-799 \cdot 0$ & 26 & $11 \cdot 1$ & $20 \cdot 7$ & 74 & $11 \cdot 5$ & $20 \cdot 1$ \\
\hline $5177-799 \cdot 2$ & 16 & $11 \cdot 5$ & $21 \cdot 2$ & 84 & $11 \cdot 6$ & $21 \cdot 1$ \\
\hline $5177-799 \cdot 4$ & 18 & $11 \cdot 3$ & $20 \cdot 8$ & 82 & $11 \cdot 5$ & $20 \cdot 3$ \\
\hline $5177-799 \cdot 8$ & 87 & $11 \cdot 6$ & $19 \cdot 6$ & 13 & $11 \cdot 0$ & $21 \cdot 3$ \\
\hline
\end{tabular}

Yields are expressed as percentages of $\mathrm{CO}_{2}$ released.

*Whole rock, non-selective analyses of dolomite-magnesite samples.
1976; Veizer et al., 1992a,b). In the Holocene, several episodes in which dolomite formed as a direct precipitate from lake water have been reported from Lake Walyungup, Western Australia (Coshell et al., 1998), and the Coorong dolomite from South Australia has also been interpreted as a direct primary precipitate from lake water (Von der Borch, 1965; Rosen et al., 1988, 1989).

Most magnesite forms as a minor mineral during diagenesis in a hypersaline environment. However, in places, hydromagnesite occurs as a primary precipitate, i.e. Salda Gölü, south-western Turkey (Braithwaite \& Zedef, 1994, 1996).

Petrographic data obtained from the TF suggest that the micritic magnesite could only have originated during early diagenesis if dolomite is a primary precipitate. The micritic magnesite replaced dolomite before the major portion of the burial carbonate cements formed. However, the crystalline and coarsely crystalline neomorphic magnesite that replaced micritic magnesite grew during late diagenesis and metamorphism. 

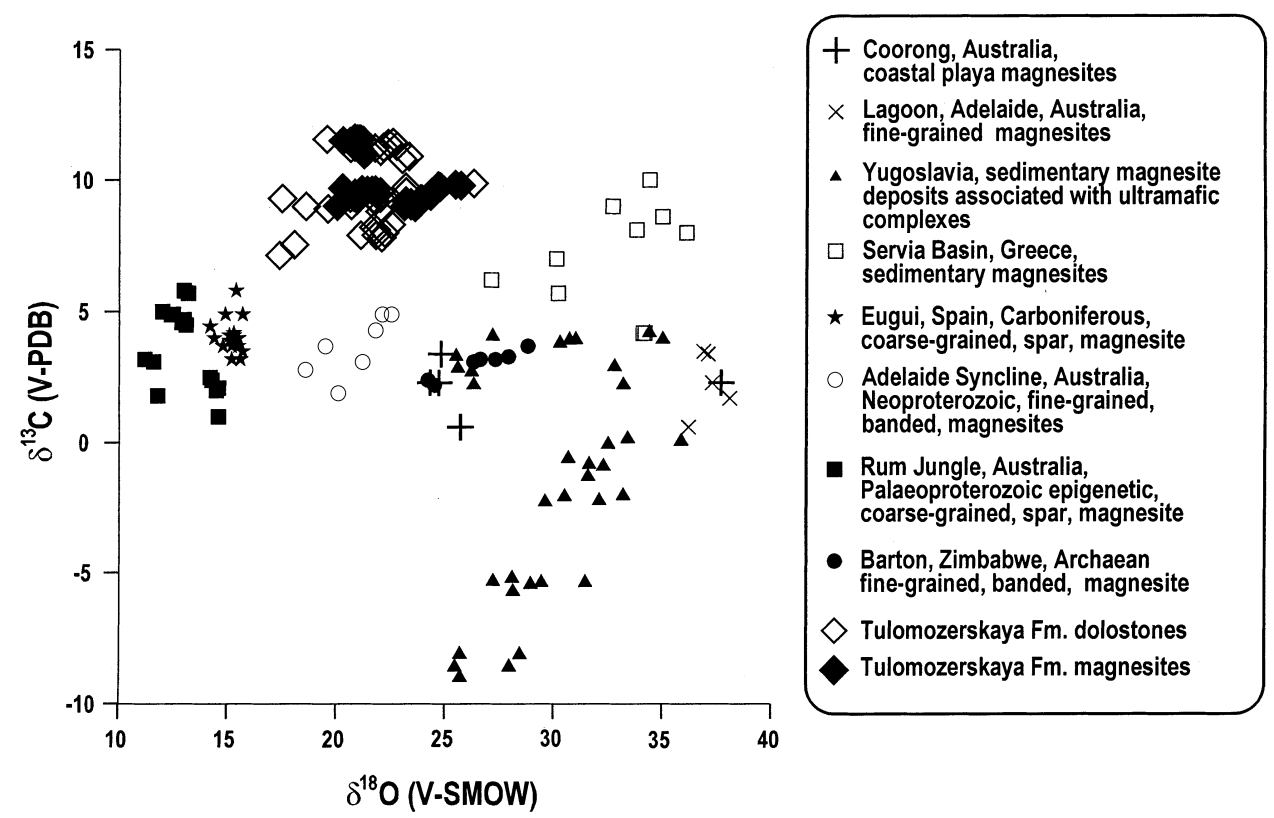

Fig. 6. Plot of $\delta^{13} \mathrm{C}$ vs. $\delta^{18} \mathrm{C}$ comparing the TF results with magnesites from other deposits. Data are from: Coorong Lagoon, South Australia (Zachmann, 1989); Lagoon, Adelaide, South Australia (Botz \& von der Borch, 1984; Schroll et al., 1986); magnesite deposits of Yugoslavia (Fallick et al., 1991); Servia sedimentary magnesites (Kralik et al., 1989); Eugui, Spain, Carboniferous, coarse-grained, spar magnesite (Kralik \& Hoefs, 1978); Adelaide Syncline, Copper Claim, Australia, Neoproterozoic, fine-grained, banded magnesite (Lambert et al., 1984); Rum Jungle, Northern Territory, Australia, Palaeoproterozoic, coarse-grained, spar magnesite (Aharon, 1988); Barton, Zimbabwe, Archaean, fine-grained, banded magnesite (Perry \& Tan, 1972; Schidlowski et al., 1975).

Several geochemical screening methods are available to assess the degree of diagenetic and metamorphic alteration. Hudson (1977) found that oxygen isotopes may be a sensitive indicator of diagenetic alteration. Diagenesis commonly decreases $\delta^{18} \mathrm{O}$, and the effect of diagenesis can be revealed on a $\delta^{13} \mathrm{C}$ and $\delta^{18} \mathrm{O}$ cross-plot. Oxygen isotopes are commonly much more easily affected by exchangeable oxygen derived from either meteoric water or interstitial fluids at elevated temperatures (e.g. Fairchild et al., 1990), whereas $\delta^{13} \mathrm{C}$ may be buffered by the pre-existing carbonate. In general, depletion in both oxygen and carbon isotope values may be considerable during late diagenesis as well as in the course of lowgrade metamorphism accompanied by deformation (Guerrera et al., 1997).

Although a $\delta^{13} \mathrm{C}-\delta^{18} \mathrm{O}$ cross-plot (Fig. 6) shows no reliable correlation, the wide spread in $\delta^{18} \mathrm{O}$ values is evident and may reflect resetting of oxygen isotopes during later recrystallization. If the highest $\delta^{18} \mathrm{O}$ values of $26 \cdot 3 \%$ for dolomite and $25 \cdot 7 \%$ for magnesite are considered as the least altered, then all the lower values could have been affected by later diagenetic and metamorphic resetting. A limited spread in $\delta^{13} \mathrm{C}$ values suggests that carbon isotopes may have been buffered by pre-existing carbonate. It is very unlikely that fluid-rock interactions during the course of metamorphism substantially affected carbon and oxygen isotope systems, as oxygen and carbon isotope values are not significantly depleted. However, $\mathrm{Mn}$ enrichment in the structureless crystalline magnesite could indicate the incorporation of later diagenetic and metamorphic Mn-rich fluids.

\section{ORIGIN OF Mg-RICH CARBONATES FROM SEDIMENTARY ENVIRONMENTS: GENERAL}

\section{Depositional environments}

Typical sedimentary magnesites are confined to: (i) ancient marine platform carbonates ('Veitsch type'; Pohl, 1989); (ii) lacustrine sediments near to or overlying ultramafic rocks (e.g. Bela Stena, Nevada; Fallick et al., 1991); (iii) marine evaporates (e.g. Sebkha el Melah, east coast of Tunisia; Perthuisot, 1980); (iv) recent coastal salt flats in arid regions (e.g. sabkhas of Abu Dhabi; Bush, 1973); and (v) continental and coastal lakes (e.g. playas in Coorong Lagoon area, South Australia; Walter et al., 1973; Schroll, 1989). 
Most magnesite forms as a minor mineral during diagenesis in a hypersaline environment. In places, hydromagnesite occurs as a primary precipitate associated with active stromatolites, i.e. Salda Gölü, south-western Turkey (Braithwaite \& Zedef, 1994, 1996). The association of stromatolites and both diagenetic and primary magnesite is very common and has been reported from many recent alkaline lakes (Walter et al., 1973; Last \& De Deckker, 1990; Renaut, 1993; Coshell et al., 1998).

\section{Source of Mg-rich solutions}

In general, the origin of Mg-bearing solutions forming sedimentary magnesites is not well understood, although some authors suggest that it does not form as a primary phase under surface conditions (e.g. Möller, 1989). The formation of magnesite requires high $\mathrm{Mg}^{2+} / \mathrm{Ca}^{2+}$ ratios in solution (Müller et al., 1972; Möller, 1989). It is well known that $\mathrm{Mg}^{2+}$ is enriched in sea water during carbonate sedimentation. This process enhances the dolomitization of carbonate muds (Carpenter, 1980) and may proceed towards magnesitization. The influence of algae in producing high $\mathrm{pH}$-values in the water may be an important factor for magnesite formation; major fossil magnesite deposits are intimately associated with biohermal stromatolitic dolomite (Misra \& Valdiya, 1961; Valdiya, 1969, 1995; Raha, 1980; Shevelev et al., 1991; Joshi et al., 1993). The salinity of the diagenetic pore solutions is very important, as rising salinity enlarges the stability field of magnesite compared with that of dolomite. The $\mathrm{Mg} / \mathrm{Ca}$ ratio is raised even more if sulphates crystallize (Bathurst, 1975), leading to the development of dense, Mg-enriched brines.

\section{Major processes controlling oxygen and carbon isotope compositions}

Carbon and oxygen isotope measurements from 74 magnesite occurrences were reviewed by Kralik et al. (1989). These data demonstrate that cryptocrystalline-microcrystalline magnesites in ultramafic complexes are characterized by low $\delta^{13} \mathrm{C}$ values ( $-6 \%$ to $-18 \%$ ) and relatively high $\delta^{18} \mathrm{O}$ values $\left(+22 \%\right.$ to $+29 \%$ oo . The negative $\delta^{13} \mathrm{C}$ and relatively high $\delta^{18} \mathrm{O}$ values indicate the formation of magnesite at low temperatures with a meteoric carbon source (Kralik et al., 1989). A study of magnesite associated with ultramafic rocks of Yugoslavia by Fallick et al. (1991) suggested a carbon source derived from decarboxy- lation of organic material for magnesite deposits with $\delta^{13} \mathrm{C}<-10 \%$.

The fine-grained Quaternary to Recent magnesites, which occur in evaporitic sabkha and local pond environments, exhibit relatively high $\delta^{13} \mathrm{C}$ $(+1 \cdot 7 \%$ to $+4 \cdot 6 \%$ oo $)$ and $\delta^{18} \mathrm{O}$ values $(+32 \%$ to $+38 \%$ ). Kralik et al. (1989) reported that these values suggest magnesite precipitation in equilibrium with a dissolved inorganic carbon pool of ambient basinal water, with the generation of isotopically very heavy carbon by fermentation.

Ancient fine-grained magnesites show two main maxima $\delta^{13} \mathrm{C}\left(+2 \%\right.$ to $+3 \%$ oo, $\delta^{18} \mathrm{O}(+25 \%$ to $+27 \%$ ) and $\delta^{13} \mathrm{C}(-2 \%$ to $-6 \%$ oo $), \delta^{18} \mathrm{O}(+18 \%$ to $+22 \%$ ). The ${ }^{13} \mathrm{C}$ enrichments are interpreted to result from carbon inheritance from an evaporitic carbonate precursor (e.g. Kralik \& Hoefs, 1978). A mixture of evaporitic and meteoric waters has been suggested as a parent fluid for the finegrained magnesite with negative carbon and low $\delta^{18} \mathrm{O}$ (Kralik et al., 1989).

The coarse-grained spar magnesites exhibit a wide range of $\delta^{13} \mathrm{C}\left(-7 \cdot 5 \%\right.$ to $+4 \%$ oo and $\delta^{18} \mathrm{O}(+6 \%$ to $+25 \%$ ). These values partly correlate with the degree of metamorphism, without evidence of magnesite formation before recrystallization (Kralik et al., 1989).

Carbon and oxygen isotope compositions of sedimentary-hosted magnesites from the main types of deposits are plotted in Fig. 6 in comparison with the TF magnesite.

\section{ORIGIN OF Mg-RICH CARBONATES: APPLICATION TO THE TF MAGNESITE}

\section{Mechanism of ${ }^{13} \mathrm{C}$ enrichment}

The TF dolomite and magnesite exhibit extreme ${ }^{13} \mathrm{C}$ enrichment. The formation of ${ }^{13} \mathrm{C}$-rich dolostones has been ascribed to the global 2.4-2.06 Ga positive excursion of carbonate ${ }^{13} \mathrm{C} /{ }^{12} \mathrm{C}$ associated with enhanced accumulation of $\mathrm{C}_{\text {org }}$ (Baker \& Fallick, 1989; Yudovich et al., 1991; Karhu, 1993; Melezhik et al., 1999). A detailed study of the TF dolostones by Melezhik et al. (1999) suggested that, although the formation of the $\mathrm{TF}^{13} \mathrm{C}$-rich carbonates was driven by global factors, the complementary organic carbon was buried in an external basin. However, it has also been reported that $\mathrm{TF}$ dolostones reveal the greatest enrichment in ${ }^{13} \mathrm{C}\left(\delta^{13} \mathrm{C}\right.$ up to $+18 \%$; Yudovich et al., 1991) known from this interval. Such enrichment exceeds the global value for the isotopic shift at $\approx 2 \cdot 0$ Ga (perhaps at around $+5 \%$; Melezhik et al., 
1997 , 1999). If the global $\delta^{13} \mathrm{C}$ value of $+5 \%$ was caused by enhanced $\mathrm{C}_{\text {org }}$ burial, the further enrichment requires an extra ${ }^{13} \mathrm{C}$-rich source(s). Development of abundant stromatolite-forming microbial communities in shallow-water basins, establishment of evaporative and partly restricted environments, high bioproductivity, enhanced uptake of ${ }^{12} \mathrm{C}$ and penecontemporaneous recycling of organic material in cyanobacterial mats with the production and consequent loss of $\mathrm{CO}_{2}$ (and $\mathrm{CH}_{4}$ ?) have been suggested to be additional factors that may have increased $\delta^{13} \mathrm{C}$ from $+5 \%$ up to $+18 \%$ o (Melezhik et al., 1999).

The $\delta^{13} \mathrm{C}$ and $\delta^{18} \mathrm{O}$ values of the TF magnesite do not differ significantly from those reported for the associated TF dolostones. Thus, we assume that both magnesite and dolomite obtained their carbon from the same reservoir and a similar mechanism was involved in the carbon isotope fractionation. Therefore, the ${ }^{13} \mathrm{C}$-rich nature of the carbon source can be assigned to both (i) the global carbon reservoir at $2 \cdot 0 \mathrm{Ga}$ and (ii) the local reservoir. At this stage, however, a quantitative separation between the local and global carbon reservoirs is not possible. If the global $\delta^{13} \mathrm{C}$ value is assumed to have been around $+5 \%$ (e.g. Melezhik et al., 1997, 1999), then the $\delta^{13} \mathrm{C}$ of $+9 \cdot 0 \%$ o to $+11 \cdot 6 \%$ can be explained as resulting from local factors, such as evaporation and restricted environments with high bioproductivity.

\section{Depositional environments and the source of Mg-rich solutions}

As discussed previously, the depositional settings of the major magnesite units (Beds 3-5) appear to have been either sabkha to playa environments or ponds in an upper tidal flat.

Epigenetic formation of magnesite seems unlikely, as carbon and oxygen isotopes and $\mathrm{Sr}$ (normalized against Ca) abundances are very similar to those of the early diagenetic/sedimentary host dolomite. An external source of $\mathrm{Mg}^{2+}$ rich solutions is also unlikely, as no ultramafic rocks are documented in the area. Furthermore, lacustrine magnesites formed from ultramaficderived Mg solutions exhibit a large spread in both oxygen and carbon isotope values, with the bulk of $\delta^{13} \mathrm{C}$ being negative (Fig. 6). Therefore, sea water is the most probable source of $\mathrm{Mg}^{2+}$-rich solutions.

The $\mathrm{Mg}^{2+}$-bearing solutions were apparently created in a hypersaline environment, as indicated by the sedimentological data. Several stages of $\mathrm{Mg} / \mathrm{Ca}$ enrichment might have taken place in the basin. First, $\mathrm{Mg} / \mathrm{Ca}$ may have been enriched in sea water in the course of calcium carbonate precipitation in a partly closed marine environment. Secondly, an arid climate may have led to further evaporation of sea water-derived brine as a result of gypsum, and then halite, precipitation. Progressive evaporation and salinity increases can be traced by the development of desiccation cracks and gypsum casts in the lithofacies X dolostones and then by halite casts in lithofacies III sediments, which overly the major bed of magnesite (Bed 5, Fig. 2). With rising salinity, if calcium sulphate was precipitated, the $\mathrm{Mg} / \mathrm{Ca}$ ratio would have increased. The succession of these processes would have led to the development of dense, $\mathrm{Mg}^{2+}$-enriched residual brines. Depletion of magnesite in $\mathrm{Na}$ and $\mathrm{F}$ compared with dolomite may indicate deficiency in these components in magnesite-forming solutions, which is consistent with the proposition that magnesite formed from evolved brines that lost $\mathrm{Ca}$ and $\mathrm{Na}$ by earlier precipitation. Such $\mathrm{Mg}^{2+}$-rich brines would most probably have percolated downwards in the sedimentary sequence as well as laterally to the centre of the basin, causing magnesitization. Magnesite replaced dolomite, and $\delta^{13} \mathrm{C}$ and $\mathrm{Sr}$ concentration would have been buffered by the dolomite precursor, as the carbon isotope composition as well as the $\mathrm{Ca} / \mathrm{Sr}$ ratios of magnesitebearing rocks are indistinguishable from those of dolomite. Petrographic data suggest that the micritic magnesite could only have originated during early diagenesis if the dolomite was a primary precipitate and replaced dolomite before the major phase of burial diagenesis. However, the crystalline and coarsely crystalline, neomorphic magnesite, which replaced micritic magnesite, grew during late diagenesis and even during metamorphism.

Relatively increased $\delta^{18} \mathrm{O}$ values of the magnesites compared with the $\delta^{18} \mathrm{O}$ average of $\mathrm{TF}$ dolomite are consistent with evolved evaporitic fluids. However, the original $\delta^{18} \mathrm{O}$ values of both dolomite and magnesite are assumed to have been partially overprinted, and the magnesite is enriched in $\mathrm{Mn}$. The higher $\delta^{18} \mathrm{O}$ values and enhanced Mn concentration may be reconciled if a sea water-derived brine was mixed with Mnrich, ${ }^{18} \mathrm{O}$-depleted meteoric fluids. Alternatively, the enrichment in $\mathrm{Mn}$ and overprinting of $\delta^{18} \mathrm{O}$ values could be related to a much later stage when collapse breccia formed as a result of sulphate (and halite) dissolution.

Given the limited development of magnesite in the TF, either sabkha magnesite (similar to $\mathrm{Abu}$ 
Dhabi) or playa magnesite (similar to the Coorong Lagoon area in South Australia and Lake Walyungup in Western Australia) match available sedimentological data. The $\delta^{18} \mathrm{O}$ values of Coorong magnesite are similar to those of the $\mathrm{TF}$, although they differ in $\delta^{13} \mathrm{C}$ (the magnesites studied here are richer in ${ }^{13} \mathrm{C}$; Fig. 6). However, both magnesites and dolostones of the $\mathrm{TF}$ are enriched in ${ }^{13} \mathrm{C}$; part of a more general problem related to the global $\approx 2 \cdot 0$ Ga positive excursion of carbonate carbon.

\section{CONCLUSIONS}

1. Magnesite forms a series of 1- to 15-m-thick beds within the $\approx 2 \cdot 0$ Ga Tulomozerskaya Formation. The 680-m-thick unit is composed of a stromatolite-dolomite-'red bed' sequence formed in a complex combination of shallow-marine and non-marine, evaporitic, partly restricted environments.

2. Dolomite-collapse breccia, stromatolitic and micritic dolostones and sparry allochemical dolostones are the principal rocks hosting the magnesite beds. All dolomite lithologies have enriched $\delta^{13} \mathrm{C}$ values of $+7 \cdot 1 \%$ to $+11 \cdot 6 \%$ and $\delta^{18} \mathrm{O}$ ranging from $17 \cdot 4 \%$ o to $26 \cdot 3 \%$.

3. Magnesite occurs in different forms: structureless micritic, crystalline, coarsely crystalline and finely laminated micritic, stromatolitic magnesite. All varieties exhibit positive, highly anomalous $\delta^{13} \mathrm{C}$ values ranging from $+9 \cdot 0 \%$ to $+11 \cdot 6 \%$ and $\delta^{18} \mathrm{O}$ values of $20 \cdot 0-25 \cdot 7 \%$.

4. Micritic magnesite originated during early diagenesis and replaced dolomite before the major phase of burial. Crystalline and coarsely crystalline, neomorphic magnesite, which replaced micritic magnesite, formed during late diagenesis/metamorphism. Magnesite apparently precipitated from sea water-derived brine, perhaps diluted by meteoric fluids. Magnesitization was accomplished under evaporitic conditions (sabkha to playa lake environment), similar to the Coorong or Lake Walyungup coastal playa magnesite.

5. Extremely high $\delta^{13} \mathrm{C}$ values of magnesite and dolostones probably reflect a combined contribution from both global and local carbon reservoirs. A ${ }^{13} \mathrm{C}$-rich global carbon reservoir $\left(\delta^{13} \mathrm{C}\right.$ at around $+5 \%$ ) is related to a perturbation of the carbon cycle at $2.0 \mathrm{Ga}$, whereas the local enhancement in ${ }^{13} \mathrm{C}$ (up to $+12 \%$ ) was associated with evaporative and restricted environments with high bioproductivity.

\section{ACKNOWLEDGEMENTS}

The results were obtained within the international project INTAS-RFBR 095-928 entitled 'World-wide 2 billion-year-old isotopically heavy carbonate carbon: the evolutionary significance and driving forces'. This research has been carried out by the Geological Survey of Norway (NGU), Trondheim, jointly with the Scottish Universities Environmental Research Centre (SUERC), Glasgow, Scotland, and the Institute of Geology (IG) of the Russian Academy of Sciences, Petrozavodsk, Russia. Access to core material of the Nevskaya and Karelian Geological Expeditions is acknowledged with thanks. The field work was financially supported by Norsk Hydro. The isotope analyses were performed at SUERC supported by the Consortium of Scottish Universities and the Natural Environment Research Council. XRF analyses were performed at NGU and financed by the Kola Mineral Resource Project. Electron-probe microanalyses and electron microscope studies were carried out at the Institute of the Continental Shelf in Trondheim. IG and, partly, NGU and SUERC were supported by INTAS-RFBR 095-928.

\section{REFERENCES}

Aharon, P. (1988) A stable isotope study of magnesite from the Rum Jungle Uranium field, Australia: implications for the origin of strata-bound massive magnesite. Chem. Geol., 69, 127-145.

Akhmedov, A.M., Krupenik, V.A., Makarikhin, V.V. and Medvedev, P.V. (1993) Carbon Isotope Composition of Carbonates in the Early Proterozoic Sedimentary Basins. Printed report, Institute of Geology of the Karelian Scientific Centre, Petrozavodsk (in Russian).

Aksenov, E.M., Ignat'ev, S.V., Negrutsa, V.S. and Solonzov, L.F. (1975) Possible presence of magnesite in Jatulian carbonate deposits in southern Karelia. Trans. USSR Acad. Sci., 227, 672-675. (in Russian).

Al-Aasm, I.S., Taylor, B.E. and South, B. (1990) Stable isotope analysis of multiple carbonate samples using selective acid extraction. Chem. Geol., 80, 119-125.

Baker, A.J. and Fallick, A.E. (1989) Heavy carbon in two-billion-year-old marbles from Lofoten-Vesterålen, Norway: implications for the Precambrian carbon cycle. Geochim. Cosmochim. Acta, 53, 1111-1115.

Bathurst, R.G.C. (1975) Carbonate Sediments and Their Diagenesis, 2nd edn. Elsevier, Amsterdam, 658 pp.

Botz, R.W. and von der Borch, C.C. (1984) Stable isotope study of carbonate sediments from the Coorong Area, South Australia. Sedimentology, 31, 837-849.

Braithwaite, C.J.R. and Zedef, V. (1994) Living hydromagnesite stromatolites from Turkey. Sed. Geol., 92, 1-5. 
Braithwaite, C.J.R. and Zedef, V. (1996) Hydromagnesite stromatolites and sediments in an alkaline lake, Salda Gölü, Turkey. J. Sed. Res., 66, 991-1002.

Bush, P. (1973) Some aspects of the diagenetic history of the Sabkha in Abu Dhabi, Persian Gulf. In: The Persian Gulf (Ed. B.H. Purser), pp. 395-407. Springer-Verlag, New York.

Carpenter, A.B. (1980) The chemistry of dolomite formation. I. The stability of dolomite. In: Concepts and Models of Dolomitization (Eds D.H. Zenger, J.B. Dunham and R.L. Eithington), SEPM Spec. Publ., 28, 111-121.

Coshell, L., Rosen, M.R. and McNamara, K.J. (1998) Hydromagnesite replacement of biomineralized aragonite in a new location of Holocene stromatolites, Lake Walyungup, Western Australia. Sedimentology, 45, 1005-1018.

Curtis, R., Evans, G., Kinsman, D.J.J. and Shearman, D.J. (1963) Association of anhydrite and dolomite in the recent sediments of the Persian Gulf. Nature, 197, 679-680.

Demicco, R.V. and Hardie, L.A. (1994) Sedimentary Structures and Early Diagenetic Features of Shallow Marine Carbonate Deposits. Society of Sedimentary Geology, Tulsa, OK, USA, $265 \mathrm{pp}$.

Fairchild, I.J., Marshall, J.D. and Bertrand-Sarafati, J. (1990) Stratigraphic shifts in carbon isotopes from Proterozoic stromatolitic carbonates (Mauritania): influences of primary mineralogy and diagenesis. Am. J. Sci., 290-A, 46-79.

Fallick, A.E., Ilich, M. and Russell, M.J. (1991) A stable isotope study of the magnesite deposits associated with the alpine-type ultramafic rocks of Yugoslavia. Econ. Geol., 86, 847-861.

Folk, R.L. (1962) Spectral subdivision of limestone types. In: Classification of Carbonate Rocks (Ed. W.E. Ham), AAPG Mem., 1, 62-84.

Guerrera, A., Peacock, S.M. and Knauth, L.P. (1997) Large ${ }^{18} \mathrm{O}$ and ${ }^{13} \mathrm{C}$ depletion in greenschist facies carbonate rocks, western Arizona. Geology, 25, 943-946.

Hardie, L.A. and Shinn, E.A. (1986) Carbonate depositional environments modern and ancient, part 3: tidal flats. $Q J$. Colorado Sch. Min., 81, 1-74.

Hudson, J.D. (1977) Stable isotopes and limestone lithification. J. Geol. Soc. London, 133, 637-660.

James, N.P. (1984) Shallowing-upwards sequences in carbonates. In: Facies Models, 2nd edn (Ed. R.G. Walker), pp. 213228. St Johns, Newfoundland. Geoscience Canada Reprint Series 1. Geological Association of Canada, Toronto.

Joshi, M.N., Bhattacharya, A.K. and Anantharaman, M.S. (1993) Origin of the sparry magnesite deposits around Bauri, Almora district, Uttar Pradesh, India. Mineral. Deposita, 28, 146-152.

Karhu, J.A. (1993) Palaeoproterozoic evolution of the carbon isotope ratios of sedimentary carbonates in the Fennoscandian Shield. Geol. Surv. Finland Bull., 371, 1-87.

Kralik, M. and Hoefs, J. (1978) Die Isotopenzusammensetzung der Karbonate in der Magnesitlagerstätte Eugui Westpyrenäen. Tschermaks Mineral. Petrogr. Mitt., 25, 185-193.

Kralik, M., Aharon, P., Schroll, E. and Zachmann, D. (1989) Carbon and oxygen isotope systematics of magnesite: review. In: Magnesite. Geology, Mineralogy, Geochemistry, Formation of Mg-Carbonates (Ed. P. Möller), Monogr. Ser. Mineral Deposits, 28, 197-223.

Kretz, R. (1982) A model for distribution of trace elements between calcite and dolomite. Geochim. Cosmochim. Acta, 46, 1979-1981.

Lambert, I.B., Donnelly, T.H., Etminan, H. and Rowlands, N.J. (1984) Genesis of Late Proterozoic copper mineralisation, Copper Claim, South Australia. Econ. Geol., 79, 461-475.
Last, W.M. and De Deckker, P. (1990) Modern and Holocene carbonate sedimentology of two saline volcanic maar lakes, Southern Australia. Sedimentology, 37, 967-981.

McCrea, J.M. (1950) On the isotopic chemistry of carbonates and a paleotemperature scale. J. Chem. Phys., 18, 849-857.

Melezhik, V.A., Fallick, A.E. and Semikhatov, M.A. (1997) Could stromatolite-forming cyanobacteria have influenced the global carbon cycle at 2300-2060 Ma? Nor. Geol. Unders. Bull., 433, 30-31.

Melezhik, V.A., Fallick, A.E., Medvedev, P.V. and Makarikhin, V.V. (1999) Extreme ${ }^{13} \mathrm{C}_{\text {carb }}$ enrichment in ca. $2.0 \mathrm{Ga}$ magnesite-stromatolite-dolomite-'red beds' association in a global context: a case for the world-wide signal enhanced by a local environment. Earth-Sci. Rev., 48, 71-120.

Melezhik, V.A., Fallick, A.E., Medvedev, P.V. and Makarikhin, V.V. (2000) Palaeoproterozoic magnesite-stromatolitedolostone-'red bed' association, Russian Karelia: palaeoenvironmental constraints on the $2.0 \mathrm{Ga}$ positive carbon isotope shift. Nor. Geol. Tidsskr., 80, 163-186.

Misra, R.C. and Valdiya, K.S. (1961) The calc zone of Pithoragarh, with special reference to the occurrence of stromatolites. J. Geol. Soc. India, 2, 78-90.

Möller, P. (1989) Nucleation process of magnesite. In: Magnesite. Geology, Mineralogy, Geochemistry, Formation of Mg-Carbonates (Ed. P. Möller), Monogr. Ser. Mineral Deposits, 28, 287-292.

Müller, G., Irion, G. and Förstner, U. (1972) Formation and diagenesis of inorganic Ca-Mg-carbonates in lacustrine environment. Naturwissenschaften, 59, 158-164.

Perry, E.C. and Tan, F.C. (1972) Significance of oxygen and carbon isotope determinations in early Precambrian cherts and carbonate rocks in southern Africa. Bull. Geol. Soc. Am., 83, 647-664.

Perthuisot, J.P. (1980) Sebkha el Melah near Zaris, a recent paralic salt basin (Tunisia). In: Evaporate Deposits (Ed. G. Busson), pp. 11-17. Editions Technip, Paris.

Pohl, W. (1989) Comparative geology of magnesite deposits and occurrences. In: Magnesite. Geology, Mineralogy, Geochemistry, Formation of Mg-Carbonates (Ed. P. Möller), Mineral Deposits Monogr. Ser. 28, 1-13.

Pukhtel', I.S., Zhuravlev, D.Z., Ashikhmina, N.A., Kulikov, V.S. and Kulikova, V.V. (1992) Sm-Nd age of the Suisarskay suite on the Baltic Shield. Trans. Russ. Acad. Sci., 326, 706711 (in Russian).

Raha, P.K. (1980) Stromatolites and their bearing on the genesis of the magnesite and associated sulphide minerals within Jammu Limestone, Udhampur District, Jammu. In: Stromatolites: Characteristics and Utility (Ed. M.V.N. Murthy), Misc. Publ. Geol. Surv. India, 44, 340-144.

Reeder, R.J. (1983) Crystal chemistry of the rhombohedral carbonates. In: Carbonates: Mineralogy and Chemistry (Ed. R.J. Reeder), Mineral. Soc. Am. Rev. Mineral., 11, 1-47.

Renaut, R.W. (1993) Morphology, distribution and preservation potential of microbial mats in the hydromagnesitemagnesite playas of the Cariboo Plateau, British Columbia, Canada. Hydrobiologia, 267, 75-98.

Rosen, M.P., Miser, D.E. and Warren, J.K. (1988) Sedimentology, mineralogy and isotopic analysis of Pellet Lake, Coorong Region, South Australia. Sedimentology, 35, 105-122.

Rosen, M.P., Miser, D.E., Starcher, M.A. and Warren, J.K. (1989) Formation of dolomite in the Coorong Region, South Australia. Geochim. Cosmochim. Acta, 53, 661-669.

Rosenbaum, J.M. and Sheppard, S.M.F. (1986) An isotopic study of siderites, dolomites and ankerites at high temperatures. Geochim. Cosmochim. Acta, 50, 1147-1159. 
Rubin, D.M. and Friedman, G.M. (1977) Intermittently emergent shelf carbonates: an example from Cambro-Ordovician of eastern New York State. Sed. Geol., 19, 81-106.

Schidlowski, M., Eichmann, R. and Junge, C.E. (1975) Precambrian sedimentary carbonates: Carbon and oxygen isotope geochemistry and implications for the terrestrial oxygen-budget. Precambrian Res., 2, 1-69.

Schroll, E. (1989) Recent formation of magnesite in evaporitic environment. The example of the Coorong Lagoon (South Australia). In: Magnesite. Geology, Mineralogy, Geochemistry, Formation of Mg-Carbonates (Ed. P. Möller), Monogr. Ser. Mineral Deposits, 28, 29-34.

Schroll, E., Siegl, W. and Papesch, W. (1986) Kohlenstoff- und Sauerstoffisotopenverteilung in einigen Magnesiten. Anz. Österr. Akad. Wiss. Math. Naturw., 123, 1-4.

Shearman, D.J. (1966) Origin of marine evaporites by diagenesis. Trans. Inst. Min. Metall., B 75, 208-215.

Shevelev, A.I., Varfolomeyeva, Ye. K., Suchaleyeva, S.S. and Khayrullina, G.Z. (1991) Characteristics of the distribution of stromatolites and organic materials in magnesite-bearing complexes. In: High-Magnesian Mineral Resources (Ed. V.P. Petrov), pp. 100-111. Nauka, Moscow (in Russian).

Shinn, E.A. (1983) Tidal flat environment. In: Carbonate Depositional Environments (Eds P.A. Scholle, D.G. Bebout and C.H. Moore), AAPG Mem., 33, 173-210.

Sokolov, V.A. (ed.) (1987) The Geology of Karelia. Nauka, Leningrad (in Russian).

Southgate, P.N. (1986) Depositional environment and mechanism of preservation of microfossils, upper Proterozoic Bitter Springs Formation, Australia. Geology, 14, 683-686.

Spencer, R.J. and Lowenstein, T.K. (1990) Evaporites. In: Diagenesis (Eds I.A. McIlreath and D.W. Morrow), pp. 141146. St Johns, Newfoundland. Geoscience Canada Reprint Series 4. Geological Association of Canada, Toronto.

Tucker, M.E. (1982) Precambrian dolomites: Petrographic and isotopic evidence that they differ from Phanerozoic dolomites. Geology, 10, 7-12.

Tucker, M.E. and Wright, V.P. (1990) Carbonate Sedimentology. Blackwell, Oxford, $482 \mathrm{pp}$.
Valdiya, K.S. (1969) A new phosphatic horizon in the late Precambrian calc zone of Pithoragarh, Kumanun Himalaya. Curr. Sci., 38, 415-416.

Valdiya, K.S. (1995) Proterozoic sedimentation and Pan-African geodynamic development in the Himalaya. Precambrian Res., 74, 35-55.

Veizer, J. and Hoefs, J. (1976) The nature of $\mathrm{O}^{18} / \mathrm{O}^{16}$ and $\mathrm{C}^{13} /$ $\mathrm{C}^{12}$ secular trends in sedimentary carbonate rocks. Geochim. Cosmochim. Acta, 40, 1387-1395.

Veizer, J., Clayton, R.N. and Hinton, R.W. (1992a) Geochemistry of Precambrian carbonates. IV. Early Paleoproterozoic $(2.25 \pm 0.25 \mathrm{Ga})$ seawater. Geochim. Cosmochim. Acta, 56, $875-885$.

Veizer, J., Plumb, K.A., Clayton, R.N., Hinton, R.W. and Grotzinger, J.P. (1992b) Geochemistry of Precambrian carbonates. V. Late Paleoproterozoic seawater $(1.8 \pm 0.25 \mathrm{Ga})$. Geochim. Cosmochim. Acta, 56, 2487-2501.

Von der Borch, C.C. (1965) The distribution and preliminary geochemistry of modern carbonate sediments of the Coorong areas: South Australia. Geochim. Cosmochim. Acta, 29, 781-799.

Walter, M.R., Golubic, S. and Preiss, W.V. (1973) Recent stromatolites from hydromagnesite and aragonite depositing lakes near Coorong Lagoon, South Australia. J. Sed. Petrol., 43, 10021-11030.

Yudovich, Ya. E., Makarikhin, V.V., Medvedev, P.V. and Sukhanov, N.V. (1991) Carbon isotope anomalies in carbonates of the Karelian Complex. Geochem. Int., 28, 56-62.

Zachmann, D.W. (1989) Mg-carbonate deposit in freshwater environment. In: Magnesite. Geology, Mineralogy, Geochemistry, Formation of Mg-Carbonates (Ed. P. Möller), Monogr. Ser. Mineral Deposits, 28, 61-94.

Manuscript received 16 April 1999; revision accepted 10 August 2000. 